\title{
Motivational Aspects of Teacher Collaboration
}

\author{
Nina Kolleck* \\ Department of Social Sciences and Philosophy, Leipzig University, Leipzig, Germany
}

The mutual dependency of teacher collaboration and motivation has emerged as a promising research field. This article now sets out to systematically review peer-reviewed articles on the interconnection of these concepts. It looks at main findings, identifies ambiguities and contradictions in the constructs and highlights their contested nature. It is shown that many studies use different theoretical approaches and conceptual operationalizations. This leads to inconsistent empirical findings. In addition, teacher collaboration is often perceived as a threat to teacher autonomy. This is surprising considering that both teacher collaboration and teacher autonomy positively affect teacher motivation according to many empirical findings.

Keywords: teacher motivation, teacher collaboration, autonomy, self-determination theory, teacher development

\section{OPEN ACCESS INTRODUCTION}

Edited by:

Kay Fuller,

University of Nottingham

United Kingdom

Reviewed by:

Kerstin Drossel,

University of Paderborn, Germany

Marsha E. Modeste,

Pennsylvania State University,

United States

*Correspondence:

Nina Kolleck

n.kolleck@fu-berlin.de

Specialty section:

This article was submitted to

Leadership in Education,

a section of the journal

Frontiers in Education

Received: 17 July 2019

Accepted: 10 October 2019

Published: 24 October 2019

Citation:

Kolleck N (2019) Motivational Aspects

of Teacher Collaboration.

Front. Educ. 4:122.

doi: 10.3389/feduc.2019.00122
In recent years, scholars of educational research and psychology have increasingly turned their attention to the role and impact of both teacher motivation and teacher collaboration in different countries and educational settings (Moolenaar et al., 2012). A particular focus has been on the driving forces behind teacher collaboration. However, the role that teacher collaboration plays in teacher motivation as well as the interplay between structural aspects of collaboration and motivation are also addressed in empirical studies around the world. Whereas, the issues of teacher collaboration and teacher motivation have been addressed in different review studies, a systematic review of the interplay between them is still missing from the academic literature. Four decades after the publication of the seminal work of Lortie (1975), which set the stage for a rapidly growing research program on both teacher motivation and teacher collaboration, this article focuses on the relationship between these and searches for responses to the main research questions:

- What can studies tell us regarding the motivations of teachers to collaborate with other teachers? and

- What effects of teacher collaboration on teacher motivation are discussed in the academic literature?

To answer these questions, the article synthesizes new contributions with innovative theoretical conceptualizations and recent empirical findings; maps the conceptual, methodological and empirical advances of rich research over recent decades; outlines avenues for future research; critically analyzes the concepts used to study motivational aspects of teacher collaboration; and sketches implications for practice.

By implementing a qualitative approach to analyze the literature-which is shaped by different methodological approaches-this review does not follow a specific understanding of teacher motivation and teacher collaboration. To do so would be problematic given the fact that most studies apply different theoretical approaches and definitions of the constructs. Instead, this review 
seeks to be open for inductive findings and to reconstruct the theoretical understandings and operationalizations of the constructs of teacher motivation and teacher collaboration.

In the past, research on teacher collaboration and teacher motivation has mainly focused on the positive effects of their interdependency. A key debate within this field of study relates to the question of possible positive effects of teacher collaboration in schools, specifically concerning effects of collaborative work on the inter- and intra-individual regulation of emotions and motivation. Following this line of inquiry, scholars have started to explore the extent to which a collaborative culture influences teachers' individual satisfaction, burnout and efficacy (Han and Yin, 2016). Conversely, teacher motivation has been recognized in different empirical studies as a key factor in strengthening teaching effectiveness (Han and Yin, 2016), teacher well-being (Yıldırım, 2014), educational reform (Moolenaar, 2012), and student motivation (Vangrieken et al., 2015). It is seen as essential for school improvement, educational equality, and student success (Mintrop and Ordenes, 2017). Hence, the relevance and mutual interdependency of teacher motivation and teacher collaboration have been demonstrated in different studies (Vangrieken et al., 2015). Teachers in a collaborative school culture seem to demonstrate increased motivation.

Due to its demonstrated importance, teacher collaboration is implemented as a main principle in various school improvement projects, teacher development initiatives, and policy frameworks in different countries. To give an example, in 2001, the National Staff Development Council (a non-profit association which was established in 1969 to foster school improvement in the United States of America) introduced teacher collaboration as one of its 12 standards for quality staff development in US American schools and further strengthened collaboration in political programs such as "learning communities" (National Staff Development Council, 2001).

However, despite its relevance to research and practice, a systematic review on the mutual relationship between teacher motivation and teacher collaboration is still missing. By systematically analyzing the scientific literature, this article aims to provide a comprehensive resource for the study of teacher motivation and collaboration as well as a valuable information source for educational administrators and policymakers concerned with the promotion of teachers in educational settings around the world. A review on the interlinkages between teacher motivation and teacher collaboration is also important in order to show how schools can make sure that teachers actually want to collaborate.

The article's structure follows the systematics of the two research questions. Hence, it first describes the methodology, involving deductive as well as inductive techniques to analyze the literature and the concepts used (section Methods). It then synthesizes answers to both research questions (section Results) and conducts inductive analyses-as a means of being open to qualitative findings-and conceptual analyses (section Discussion). Subsequently, it summarizes main findings (section Summary) and discusses limitations (section Limitations). The article concludes by outlining implications for research and practice and outlining prospects for further research (section Conclusion).

\section{METHODS}

\section{Systematic Literature Search}

Literature was collected in the period December 2017-March 2018 using the following databases: ERIC (U.S. Dept. Of Education), PubPsych (databases included: PSYNDEX, PASCAL, ISOC-Psicología, MEDLINE ${ }^{\circledR}$, ERIC, NARCIS, NORART, PsychOpen, PsychData), Sciencedirect (Elsevier), the search engine Primo and Web of Knowledge (databases included: Web of Science, Inspec, BIOSIS Citation Index and BIOSIS Previews).

At first, several search terms were used. The most relevant literature was found with the general search terms "teacher AND motivation," "teacher AND collaboration," and "teacher AND cooperation." In addition, the more specific search terms "collective AND teacher AND efficacy" (primarily to find articles on collective teacher efficacy), "cooperative AND learning AND teacher AND education" (primarily to find articles on cooperative learning and teacher education) as well as "school AND team AND work AND motivation" (primarily to find articles on school team and work motivation) were applied. This resulted in further important findings concerning the research aims of this article. Table 1 lists the number of sources found and the number of sources selected for each of the databases according to the search terms applied for this review. The smaller number refers to the articles selected using the search terms and according to the databases.

As illustrated in Table 1, ERIC proved to be the most fruitful database. Nine articles found with ERIC were used for the analysis of this article.

Relevant literature was selected in three steps following guidelines for review articles (Bearman et al., 2013). First, the titles and abstracts were studied to eliminate all articles that had no connection with the central research topics of this article. Second, the introductory and final sections were analyzed. Based on this analysis, studies were excluded according to the following criteria:

- The articles did not refer to both issues, i.e., teacher collaboration and teacher motivation.

- The collaboration and motivation discussed did not pertain to school teachers (e.g., no primary educators, high school educators).

- The research studied relations between two or three individuals only.

Moreover, the database was limited to peer-reviewed journal articles published since 1990 and dealing with teacher motivation and collaboration. Non-research articles (e.g., practical guidelines) were excluded. Third, all remaining relevant articles were read in detail. Subsequently, the snowball technique was used to detect further relevant articles. For articles detected through the snowball approach, the same criteria for selection and elimination were used to distinguish relevant and unrelevant references for this study. 
TABLE 1 | Findings according to database and keywords and sources selected for this review (including the number of articles found through snowballing).

\begin{tabular}{|c|c|c|c|c|c|c|}
\hline Search terms & & ERIC & PubPsych & $\begin{array}{c}\text { Web of } \\
\text { knowledge }\end{array}$ & ScienceDirect & Primo \\
\hline $\begin{array}{l}\text { Teacher AND motivation } \\
\text { (AND social network } \\
\text { OR organizational learning } \\
\text { OR team building OR team work } \\
\text { OR team) }\end{array}$ & $\begin{array}{l}\text { Results } \\
\text { Selection }\end{array}$ & $\begin{array}{c}10.796 \\
2\end{array}$ & $\begin{array}{c}1.862 \\
-\end{array}$ & $\begin{array}{c}6.773 \\
-\end{array}$ & $\begin{array}{c}53.624 \\
-\end{array}$ & $\begin{array}{c}576.587 \\
2\end{array}$ \\
\hline $\begin{array}{l}\text { Teacher collaboration } \\
\text { (AND motivation OR collaboration } \\
\text { AND teacher motivation OR teacher education) }\end{array}$ & $\begin{array}{l}\text { Results } \\
\text { Selection }\end{array}$ & $\begin{array}{c}9.462 \\
6\end{array}$ & $\begin{array}{c}552 \\
-\end{array}$ & $\begin{array}{c}3.801 \\
1\end{array}$ & $\begin{array}{c}33.652 \\
6\end{array}$ & $\begin{array}{c}397.658 \\
3\end{array}$ \\
\hline $\begin{array}{l}\text { Teacher AND cooperation } \\
\text { (AND motivation) }\end{array}$ & $\begin{array}{l}\text { Results } \\
\text { Selection }\end{array}$ & $\begin{array}{c}10.567 \\
3\end{array}$ & $\begin{array}{c}1.044 \\
-\end{array}$ & $\begin{array}{c}1.087 \\
-\end{array}$ & $\begin{array}{c}30.101 \\
-\end{array}$ & $\begin{array}{c}395.597 \\
-\end{array}$ \\
\hline Collective teacher efficacy & $\begin{array}{l}\text { Results } \\
\text { Selection }\end{array}$ & $\begin{array}{c}159 \\
2\end{array}$ & $\begin{array}{l}49 \\
-\end{array}$ & $\begin{array}{c}223 \\
-\end{array}$ & $\begin{array}{c}5.070 \\
-\end{array}$ & $\begin{array}{c}104.074 \\
-\end{array}$ \\
\hline Cooperative learning AND teacher education & $\begin{array}{l}\text { Results } \\
\text { Selection }\end{array}$ & $\begin{array}{c}3.845 \\
-\end{array}$ & $\begin{array}{c}255 \\
-\end{array}$ & $\begin{array}{c}427 \\
-\end{array}$ & $\begin{array}{c}11.991 \\
-\end{array}$ & $\begin{array}{c}243.416 \\
-\end{array}$ \\
\hline School AND team work AND motivation & $\begin{array}{l}\text { Results } \\
\text { Selection }\end{array}$ & $\begin{array}{l}57 \\
-\end{array}$ & $\begin{array}{l}41 \\
-\end{array}$ & $\begin{array}{l}83 \\
-\end{array}$ & $\begin{array}{c}37.937 \\
-\end{array}$ & $\begin{array}{c}485.970 \\
-\end{array}$ \\
\hline Total & & 13 & - & 1 & 6 & 5 \\
\hline
\end{tabular}

\section{Qualitative Narrative Analysis}

To systematically analyze the literature found for this review, the study uses qualitative narrative techniques (Petticrew and Roberts, 2006; Baumeister, 2013; Fink, 2014; Jahan et al., 2016). A qualitative approach is appropriate for this article because the studies to be analyzed are methodologically diverse. Furthermore, because the literature shows different conceptualizations and operationalizations of the constructs of collaboration and motivation, a meta-analysis would be problematic. In addition, one of the aims of this review study is to analyze the research questions against their theoretical perspectives and conceptualizations (Baumeister, 2013) and to enable a more open interpretation of the quality and results of the studies in order to detect new aspects that characterize the literature (Petticrew, 2015).

Research articles were investigated drawing on both "withinstudy" and "between-study" literature analysis (Onwuegbuzie et al., 2012). Hence, each of the articles detected for this review was examined in detail concerning its title, literature cited, methods and theories used, conceptualizations, argumentations, and the discussion. For the between-study analysis, all articles analyzed were compared. Both the within-study and betweenstudy approaches included deductive and inductive techniques. First, categories were developed based on the research questions outlined abovein order to deductively filter the literature found for this review study. Subsequently, the selected literature was re-analyzed inductively with the aim to be open to new findings and to move from specific observations to broader generalizations and theories. This final analysis proved to be the most important for this study because it started with specific observations-detecting patterns and regularities and summarizing and systematically comparing these-and finally ended up developing more general observations including
TABLE 2 | Articles analyzed for this review according to the methods used.

theoretical reasoning. Protocols, tables, and summaries were prepared for each of the steps of the analysis. Due to the high number of articles selected for this review study, it is only possible to present summaries of these steps in this article (see Table 3B for a collection of all reviewed studies). Two other researchers checked the selection of relevant literature (i.e., the search terms used and articles found) as well as "within-study" and "betweenstudy" analysis results, the categorizations and the comparisons.

\section{Description of the Database}

Altogether, the literature review resulted in a total of 25 sources (see Table 1, which also presents the number of articles selected according to each database). The majority of the articles found use an empirical approach based on quantitative methods (a total of 12). Eleven studies apply qualitative techniques and two use a mixed-methods approach. A purely conceptual or review approach was not applied in any of the selected studies (see Table 2). The current review includes quantitative and qualitative studies, although integrating these approaches poses difficulties in terms of standardized search terms and synthesizing the results of the studies.

While many scholars have stressed the value of integrating qualitative and quantitative studies, there have been only few 
reviews that also include qualitative studies though this is becoming more common (Petticrew and Roberts, 2006). This is even the case for research topics such as teacher motivation and teacher collaboration, which are characterized by inconsistent conceptualizations. In such cases, a standardized analysis is extremely difficult. One reason for this phenomenon can be found in the perception that results of qualitative studies are often regarded as supporting quantitative research. Qualitative designs are often used to generate hypotheses or even research questions, but often excluded from evidence-based studies or studies on educational effectiveness. So far, systematic reviews have mostly been focused on evidence and impacts or measuring effects. Thus, including qualitative studies in systematic reviews requires a change of perspective and the incorporation of qualitative evidence. This may involve, for instance, including different types of studies and identifying new dimensions of impact or forgotten aspects. To give an example, Vangrieken et al. (2015) include qualitative and mixed-methods studies in their review in order to evaluate how the literature uses methodological approaches and theoretical constructs of teacher collaboration. Qualitative studies do not offer robust information about the effects of interventions, but they do provide more detailed information on "what matters," i.e., the meanings and processes. "Systematic reviewing $[\ldots]$ can deal with a variety of questions, study designs, and methods within the same review" (Petticrew and Roberts, 2006, p. 57). Furthermore, this review includes conceptual contributions and reviews (e.g., De Brabander and Martens, 2014) because they provided information on the theoretical conceptualization and empirical operationalization of the terms teacher collaboration and teacher motivation. They prove to be helpful to understand the findings and to synthesize the review findings.

\section{RESULTS}

In this section, the findings of the qualitative analysis are presented and contextualized against the guiding research questions and aims presented above. Table $\mathbf{3 A}$ gives an overview of the selected studies, the concepts used, and their main findings.

\section{What Motivates Teachers to Collaborate?}

Different reasons for teacher collaboration can be found in the literature (e.g., Drossel et al., 2018). This subsection discusses answers found within the scientific literature to the first research question of what motivates teachers to collaborate. It starts with motivational factors found at the personal level and those related to attributes and team behavior. It then outlines factors associated with leadership practices and organizational frameworks. Building on this, it presents motivational factors relating to work conditions and supporting tools and then outlines factors that motivate teachers at the macro level, i.e., policies and development programs. Finally, constraints on collaboration are discussed as factors impeding teacher collaboration.

\section{Attributes and Team Behavior}

The motivation to collaborate is influenced by teachers' personal attributes such as age (i.e., older teachers are found to collaborate to a lesser degree than their younger colleagues), gender (i.e., female teachers are more likely to cooperate than male teachers), and experience (i.e., teacher collaboration is higher among novice teachers) (e.g., Mora-Ruano et al., 2018). Runhaar et al. (2010) show that self-efficacy and learning goal orientation are positively related to asking for feedback (Runhaar et al., 2010). Teachers with a strong sense of efficacy who believe in their capabilities to achieve goals are more likely to engage in structured collaboration and improvement strategies (Runhaar et al., 2010; Thoonen et al., 2011). Based on an expectancyvalue model of teacher motivation, Drossel et al. (2018) show that subjective values explain teachers' motivation to collaborate. The personal relevance of collaboration for teachers and their subjective values also relate to teachers' perceptions of their principals as well as their personal tendency to collaborate. Teachers' self-efficacy and collective efficacy are further positively related to extra-role behavior, that is a behavior that exceeds the requirements of a teacher's role to voluntarily support a team's or a school's goals (Somech and Drach-Zahavy, 2000). In addition, higher levels of teamwork in schools reinforce teachers' team commitment in cases where teachers possess appropriate teamwork skills. For example, communication skills enable teachers to become more effective participants in collaboration endeavors (Donnellon, 1996).

\section{Leadership Practices and Organizational Frameworks}

In the literature on teacher collaboration, a collaborative culture is mostly associated with leadership practices. It is frequently argued that strong engagement of the department head increases the chances of teacher collaboration. Collective efficacy, in turn, serves as an intervening variable for student achievement.

Honingh and Hooge (2014) claim that in past research, teacher collaboration has mostly been regarded as an intermediate variable, leading to a lack of evidence on both the extent to which teachers collaborate and the aspects that influence teacher collaboration (Honingh and Hooge, 2014). As a response, they carry out secondary data analyses on teacher collaboration in both primary and secondary schools in the Netherlands with the aim to analyze the extent to which "teachers in primary and secondary schools collaborate, and which school and teacher characteristics affect their collaboration" (Honingh and Hooge, 2014, p. 76). They find that teacher collaboration is influenced by both the organizational framework and teachers' personal characteristics. With respect to primary schools, teacher collaboration is mostly influenced by teachers' perception of taking part in decision-making, teachers' positioning toward student performance, and their satisfaction with school-leader support. In contrast, in secondary schools teacher collaboration seems to be better explained by school-leader support (Honingh and Hooge, 2014).

The positive effects of teacher participation in decisionmaking on both teacher collaboration and teacher commitment is also shown by Devos et al. (2014). In a study on the relationship between principals and teaching staff, they find 
TABLE 3A | Overview: Articles selected for further review.

\begin{tabular}{|c|c|c|c|c|c|c|}
\hline No. & References & Method & Theoretical approach & Central results & Motivation concept & Collaboration concept \\
\hline 1. & $\begin{array}{l}\text { Clement and } \\
\text { Vandenberghe } \\
\text { (2000) }\end{array}$ & Qualitative & Grounded theory & $\begin{array}{l}\text { The article analyzes the relation between teachers' collegiality } \\
\text { and autonomy. Teachers are motivated to collaborate if } \\
\text { collaboration supports learning opportunities. At the same } \\
\text { time, many teachers are more motivated if they work on their } \\
\text { own or autonomously. }\end{array}$ & Motivation to collaborate & $\begin{array}{l}\text { Concept of Collegiality } \\
\text { according to (Little, 1990) }\end{array}$ \\
\hline 2. & $\begin{array}{l}\text { Coburn and } \\
\text { Russel (2008) }\end{array}$ & Qualitative & $\begin{array}{l}\text { Social capital } \\
\text { theory/Social } \\
\text { network analysis }\end{array}$ & $\begin{array}{l}\text { The article argues that differences in policy provisions affect } \\
\text { social teachers' interactions. Trust plays a fundamental role in } \\
\text { these interactions because it leads to information sharing in } \\
\text { teacher networks. }\end{array}$ & $\begin{array}{l}\text { No specific } \\
\text { motivation concept }\end{array}$ & $\begin{array}{l}\text { Professional (learning) } \\
\text { communities }\end{array}$ \\
\hline 3. & $\begin{array}{l}\text { Collinson and } \\
\text { Cook (2004) }\end{array}$ & Qualitative & No specific theory & $\begin{array}{l}\text { Factors motivating teachers to collaborate are for the most } \\
\text { part internal and relate to teachers' professional judgments, } \\
\text { attitudes, and relationships. Factors restraining teachers from } \\
\text { collaboration are mostly external and relate to the structure of } \\
\text { the school schedule and the lack of time. }\end{array}$ & Motivation to collaborate & $\begin{array}{l}\text { Focus on sharing of } \\
\text { knowledge, skills, and } \\
\text { insights }\end{array}$ \\
\hline 4. & $\begin{array}{l}\text { Conley et al. } \\
\text { (2004) }\end{array}$ & Quantitative & $\begin{array}{l}\text { Hackman and } \\
\text { Oldham's (1980) work } \\
\text { group } \\
\text { effectiveness model }\end{array}$ & $\begin{array}{l}\text { Motivating job characteristics and team autonomy predict } \\
\text { work group effectiveness and teachers' perceptions to } \\
\text { support team commitment. Group work motivates group } \\
\text { members and provides autonomy. }\end{array}$ & $\begin{array}{l}\text { Motivation to work } \\
\text { (operationalized by e.g., } \\
\text { autonomy and interaction } \\
\text { with others) }\end{array}$ & $\begin{array}{l}\text { Operationalized as } \\
\text { interdisciplinary teacher } \\
\text { teams }\end{array}$ \\
\hline 5. & Devos et al. (2014) & Quantitative & $\begin{array}{l}\text { Distributed } \\
\text { leadership approach }\end{array}$ & $\begin{array}{l}\text { The study focuses on teachers' perception of collaboration } \\
\text { and shows that teachers' organizational commitment, group } \\
\text { cohesion and the degree of goal orientation of team members } \\
\text { positively influences teachers' perception of collaboration. }\end{array}$ & $\begin{array}{l}\text { Affective } \\
\text { organizational commitment }\end{array}$ & $\begin{array}{l}\text { Cooperation within the } \\
\text { leadership team and } \\
\text { participative } \\
\text { decision-making of teachers }\end{array}$ \\
\hline 6. & $\begin{array}{l}\text { Drossel et al. } \\
(2018)\end{array}$ & Quantitative & $\begin{array}{l}\text { Expectancy } \\
\text { value theory }\end{array}$ & $\begin{array}{l}\text { Cooperation among teachers depends on teachers' } \\
\text { subjective values, but not on their expectation of success. } \\
\text { The subjective value component is the only decisive factor of } \\
\text { the expectancy value model chosen for the study to explain } \\
\text { why teachers cooperate [according to the types of teacher } \\
\text { cooperation proposed by Gräsel et al. (2006)]. }\end{array}$ & $\begin{array}{l}\text { Expectancy value model } \\
\text { (Eccles and Wigfield, 2002) } \\
\text { to analyze teachers' } \\
\text { motivation to collaborate. }\end{array}$ & $\begin{array}{l}\text { Subdivided into three } \\
\text { categories: exchange, } \\
\text { synchronization, and } \\
\text { co-construction (Gräsel } \\
\text { et al., 2006) }\end{array}$ \\
\hline 7. & $\begin{array}{l}\text { Durksen et al. } \\
\text { (2017) }\end{array}$ & Mixed Methods & $\begin{array}{l}\text { Social cognitive theory, } \\
\text { demands-resources } \\
\text { theory and self- } \\
\text { determination theory }\end{array}$ & $\begin{array}{l}\text { The article analyzes teacher motivation and teachers' learning } \\
\text { with a strong emphasis on teacher collaboration. A positive } \\
\text { relationship between motivational constructs and } \\
\text { collaborative learning is shown. }\end{array}$ & $\begin{array}{l}\text { Combination of social } \\
\text { cognitive theory, } \\
\text { demands-resources theory } \\
\text { and } \\
\text { self-determination theory }\end{array}$ & $\begin{array}{l}\text { Focus on collaborative } \\
\text { learning and relatedness } \\
\text { according to } \\
\text { self-determination theory }\end{array}$ \\
\hline 8. & $\begin{array}{l}\text { English and } \\
\text { Duncan-Howell } \\
\text { (2008) }\end{array}$ & Qualitative & $\begin{array}{l}\text { No specific } \\
\text { theoretical approach }\end{array}$ & $\begin{array}{l}\text { Web } 2.0 \text { tools such as Facebook seem to motivate } \\
\text { pre-service teachers to pick up communication with each } \\
\text { other more frequently for the purpose of mostly affective } \\
\text { communication such as encouragement and support but also } \\
\text { for solving problems. }\end{array}$ & $\begin{array}{l}\text { Motivation to teach/to } \\
\text { handle problems in } \\
\text { practicum }\end{array}$ & $\begin{array}{l}\text { Online community software } \\
\text { (i.e., Facebook group) }\end{array}$ \\
\hline 9. & $\begin{array}{l}\text { Egodawatte et al. } \\
\text { (2011) }\end{array}$ & Qualitative & No specific theory & $\begin{array}{l}\text { The article analyzes the effects of a collaborative inquiry } \\
\text { project with grade } 9 \text { applied mathematics teachers and } \\
\text { discusses how it improves professional development. }\end{array}$ & $\begin{array}{l}\text { No specific } \\
\text { motivation concept }\end{array}$ & $\begin{array}{l}\text { Collaborative model that } \\
\text { values consensus building } \\
\text { with a focus on relations } \\
\text { between universities and } \\
\text { schools. }\end{array}$ \\
\hline
\end{tabular}


TABLE 3A | Continued

Teacher collaboration has personal (job satisfaction, support) and organizational benefits (e.g., sense of identity in the school community). Teacher collaboration is enhanced by school leadership, informed staff, personal and professional motivation, willingness to change and improve, and communication. Political and collaborative motivation factors are less important than practical and emancipatory factors in fostering teacher collaboration.

11. Goddard et al. Quantitative

Social cognitive (2000) theory/collective teacher efficacy

\section{Hew and Hara} (2007)

Qualitative

Communities of practice

The authors develop an operational measure of collective teacher efficacy and show that social cognitive theory can be applied at the organizational level. Teachers' shared beliefs influence the school's culture, norms, actions, and achievements.

The article explores the motivators and the barriers of teacher online knowledge sharing. Collectivism and principals appear to be the main motivators; lack of knowledge and competing priorities seem to hinder teachers from online knowledge sharing.

13. Honingh and Hooge (2014)

Quantitative

School leadership approach

The study shows how teacher collaboration is shaped by organizational and teachers' personal characteristics. While teacher collaboration in secondary schools is mainly influenced by principals' support, teacher collaboration in primary schools can be further explained by teachers' participation in decision-making and teachers' positioning toward student performance.

14. Horn and Little Qualitative

Professional (2010)

learning approach

The authors apply conversational routine as a conceptual tool to assess learning processes in collaborative group interactions. They show how teachers created an interactional space through routines of normalizing, specifying, revising, and generalizing. They further argue that alterations in the generativity of group discourses are to be seen as a result of each group's collective orientation and its contextual resources and constraints.

15. Jao and Qualitative Communities

McDougall (2016) of Practice

16. Kaldi and Xafakos Mixed Methods (2017)

$17 . \quad$ Moolenaar et al.

Quantitative
The article shows barriers to collaboration and solutions that could be implemented to solve challenges and support teacher collaboration. Teachers are motivated to combat barriers when they realize the benefits of their collaboration. The article shows statistically significant correlations among external motivation, support, and perceived teaching self-competence. Social networks of support influence the development of teaching competences.

Theory of situated learning, selfdetermination theory

Social cognitive theory/collective teacher efficacy
Using Social Network Analysis, the article shows that the density of teacher networks positively correlates with

teachers' perception of collective efficacy. Hence, collective efficacy beliefs are supported by advice relationships, which appear to foster the team's shared belief.
Motivation to teach and to

develop professionally

Participation in professional development

Collective teacher efficacy

Collective teacher efficacy

Motivation to

share knowledge

Communities of practice

Motivation to collaborate

Teacher interactions concerning curriculum and instruction

No specific

motivation concept

\section{Professional}

communities/Communities of practice/Teacher work groups

Motivation to collaborate

Communities of practice

Self-determination

theory (SDT)

Relatedness according to SDT

Collective teacher efficacy 
TABLE 3A | Continued

\begin{tabular}{|c|c|c|c|c|c|c|}
\hline No. & References & Method & Theoretical approach & Central results & Motivation concept & Collaboration concept \\
\hline 18. & $\begin{array}{l}\text { Reeves et al. } \\
(2017)\end{array}$ & Quantitative & $\begin{array}{l}\text { No specific } \\
\text { theoretical approach }\end{array}$ & $\begin{array}{l}\text { Data from the Trends in International Mathematics and } \\
\text { Science Study (TIMSS) is analyzed to study effects of teacher } \\
\text { collaboration on e.g., teacher confidence in teaching and } \\
\text { teacher's job satisfaction in the USA and Japan. The analysis } \\
\text { produces mixed results. The effect of teacher collaboration } \\
\text { seems to depend on the type of teacher collaboration and } \\
\text { the cultural context (i.e., the respective country). }\end{array}$ & $\begin{array}{l}\text { Job satisfaction and teacher } \\
\text { confidence as prerequisites } \\
\text { for teacher motivation }\end{array}$ & $\begin{array}{l}\text { Types of teacher } \\
\text { collaboration according to } \\
\text { TIMSS data }\end{array}$ \\
\hline 19. & $\begin{array}{l}\text { Runhaar et al. } \\
\text { (2010) }\end{array}$ & Quantitative & $\begin{array}{l}\text { AMO-theory/Social } \\
\text { cognitive theory/Goal } \\
\text { orientation } \\
\text { theory/Transformational } \\
\text { leadership theory }\end{array}$ & $\begin{array}{l}\text { The article shows that occupational self-efficacy and asking } \\
\text { for feedback are positively related, mediated through learning } \\
\text { goal orientation. Furthermore, teachers' informal learning is } \\
\text { significantly influenced by task- and goal interdependence. }\end{array}$ & $\begin{array}{l}\text { Occupational } \\
\text { self-efficacy/Learning } \\
\text { goal orientation }\end{array}$ & Asking for feedback \\
\hline 20. & $\begin{array}{l}\text { Scribner et al. } \\
\text { (2002) }\end{array}$ & Qualitative & $\begin{array}{l}\text { Professional } \\
\text { communities/micropolitics } \\
\text { of education }\end{array}$ & $\begin{array}{l}\text { The article suggests that trustful relations between teachers } \\
\text { and the principal, and transparent decision-making } \\
\text { processes are critical for teachers' shared commitment to } \\
\text { school goals. Principals can support teachers' intrinsic } \\
\text { motivations to reach students and to develop professionally. }\end{array}$ & $\begin{array}{l}\text { Need } \\
\text { satisfaction/professional } \\
\text { autonomy }\end{array}$ & $\begin{array}{l}\text { Professional learning } \\
\text { communities }\end{array}$ \\
\hline 21. & Somech (2005) & Quantitative & $\begin{array}{l}\text { Organizational } \\
\text { citizenship behavior } \\
\text { (OCB); Empowerment } \\
\text { and Commitment }\end{array}$ & $\begin{array}{l}\text { Team empowerment may strengthen teachers' performance } \\
\text { and motivation via the fulfillment of social-psychological } \\
\text { needs, such as a sense of authority about what teachers do } \\
\text { and how they do it, a feeling of being engaged in meaningful } \\
\text { work and being respected by others. }\end{array}$ & $\begin{array}{l}\text { Need satisfaction/sense } \\
\text { of empowerment }\end{array}$ & Teamwork \\
\hline 22. & $\begin{array}{l}\text { Somech and } \\
\text { Drach-Zahavy } \\
\text { (2000) }\end{array}$ & Quantitative & $\begin{array}{l}\text { Self-efficacy and } \\
\text { collective efficacy }\end{array}$ & $\begin{array}{l}\text { The authors show benefits for teachers from collaboration. } \\
\text { The more often teacher teams meet, the more teachers are } \\
\text { motivated and committed to both the team's mission and the } \\
\text { success of the team in achieving its goals. }\end{array}$ & $\begin{array}{l}\text { Job satisfaction, self-and } \\
\text { collective efficacy }\end{array}$ & Collective efficacy \\
\hline 23. & $\begin{array}{l}\text { Szczesiul and } \\
\text { Huizenga (2014) }\end{array}$ & Qualitative & $\begin{array}{l}\text { Principal } \\
\text { leadership/socio- } \\
\text { cultural } \\
\text { perspective/Social } \\
\text { cognitive theory }\end{array}$ & $\begin{array}{l}\text { The authors explore the way teachers' social interactions } \\
\text { influence their motivation to engage in collaboration. } \\
\text { According to teachers' self-expressions, strategic scheduling } \\
\text { allowing for common planning time increases their } \\
\text { collaboration efforts. Interdependence shows a motivating } \\
\text { effect since teachers view problems as collective. }\end{array}$ & $\begin{array}{l}\text { Self-efficacy/motivation } \\
\text { to teach }\end{array}$ & $\begin{array}{l}\text { Common planning } \\
\text { time/School culture }\end{array}$ \\
\hline 24. & $\begin{array}{l}\text { Thoonen et al. } \\
\text { (2011) }\end{array}$ & Quantitative & $\begin{array}{l}\text { Framework for } \\
\text { large-scale reform } \\
\text { (Leithwood et al., } \\
\text { 2002), Expectancy- } \\
\text { value-model, } \\
\text { Social-cognitive theory }\end{array}$ & $\begin{array}{l}\text { The study analyzes the effects of teacher motivation on } \\
\text { teachers' engagement in professional learning activities and } \\
\text { shows positive effects of trusting relationships on teaching } \\
\text { practice, mediated by teachers' engagement in professional } \\
\text { learning activities as well as teacher motivation. Teachers' } \\
\text { sense of self-efficacy and their internalization of school goals } \\
\text { into personal goals are the most important explanatory } \\
\text { motivational factors in the study's model. }\end{array}$ & $\begin{array}{l}\text { Expectancy-value-(affect)- } \\
\text { model (operationalized by } \\
\text { self-efficacy, internalization } \\
\text { of school goals, tolerance of } \\
\text { uncertainty, well-being) }\end{array}$ & $\begin{array}{l}\text { Organizational conditions of } \\
\text { Professional learning } \\
\text { communities }\end{array}$ \\
\hline 25. & YIIdirm (2014) & Quantitative & $\begin{array}{l}\text { Theoretically } \\
\text { constructed model of } \\
\text { teachers' } \\
\text { professional well-being }\end{array}$ & $\begin{array}{l}\text { Teacher well-being is influenced by organizational } \\
\text { characteristics, e.g., school climate, assessment and } \\
\text { feedback and cooperation among staff and classroom } \\
\text { climate. Professional well-being is connected to teacher } \\
\text { motivation. }\end{array}$ & $\begin{array}{l}\text { Professional well-being } \\
\text { (operationalized by e.g., } \\
\text { self-efficacy and motivation) }\end{array}$ & $\begin{array}{l}\text { No specific collaboration } \\
\text { concept }\end{array}$ \\
\hline
\end{tabular}

citizenship behavio

(OCB); Empowerment

and Commitment

Self-efficacy and

Principal

leadership/socio-

elthwood et al.

value-model,

Social-cognitive theory

Theoretically

eachers'

motivation. frem the Trends in International Mathematics and

teacher's job satisfaction in the USA and Japan. The analys

elf-efficacy/Learnin

Need

atisfaction/professional

Professional learning

The authors show benefits for teachers from collaboration. According to teachers' self-expressions, strategic schedulin

effect since teachers view problems as collective.

The study analyzes the ene

shows positive effects of trusting relationships on teaching

sense of self-efficacy and their internalization of school goas

(

Teacher well-being is influenced by organizationa

characteristics, e.g., school climate, assessment and 
TABLE 3B | All articles found in line with search criteria, according to concepts used and whether or not they were selected for the review.

\begin{tabular}{|c|c|c|c|c|c|c|}
\hline No. & References & Method & Theoretical approach & Motivation concept & Collaboration concept & Selected \\
\hline 1. & Al-Natour et al. (2015) & Mixed methods & No specific theory & Motivation to collaborate & $\begin{array}{l}\text { Defined as direct interaction between at } \\
\text { least two co-equal parties who are } \\
\text { voluntarily engaged in shared } \\
\text { decision-making, working toward a } \\
\text { common goal }\end{array}$ & No \\
\hline 2. & $\begin{array}{l}\text { Ammentorp and Madden } \\
\text { (2018) }\end{array}$ & Conceptual & Partnered placement model & Motivation to work & $\begin{array}{l}\text { Collaboration conceptualized according to } \\
\text { "Partnered Placement Model" }\end{array}$ & No \\
\hline 3. & $\begin{array}{l}\text { Baleghizadeh and Gordani } \\
\text { (2012) }\end{array}$ & Mixed methods & $\begin{array}{l}\text { Noe et al.'s (1990) model of career } \\
\text { motivation and Walton (1973) model of } \\
\text { quality of work life }\end{array}$ & $\begin{array}{l}\text { Noe et al.'s (1990) model of career } \\
\text { motivation }\end{array}$ & No specific collaboration concept & No \\
\hline 4. & $\begin{array}{l}\text { Benoliel and Schechter } \\
\text { (2017) }\end{array}$ & Conceptual & Five factor model & $\begin{array}{l}\text { Teachers'motivation to share knowledge in } \\
\text { the educational context }\end{array}$ & Professional learning communities & No \\
\hline 5. & Bigsby and Firestone (2017) & $\begin{array}{l}\text { Mixed methods } \\
\text { (social network } \\
\text { analysis) }\end{array}$ & Social capital approach & Motivators of participation & $\begin{array}{l}\text { Participation in professional } \\
\text { development program }\end{array}$ & No \\
\hline 6. & $\begin{array}{l}\text { Chapman and Hadfield } \\
\text { (2010) }\end{array}$ & Conceptual & $\begin{array}{l}\text { The article aims to develop a theoretical } \\
\text { framework on school-based networks }\end{array}$ & $\begin{array}{l}\text { Motivation to collaborate in a } \\
\text { school-based network }\end{array}$ & School-based networks & No \\
\hline 7. & $\begin{array}{l}\text { Ciampa and Gallagher } \\
\text { (2016) }\end{array}$ & Qualitative & Social cognitive theory (Bandura, 2005) & Self-efficacy & Teacher collaborative inquiry & No \\
\hline 8. & $\begin{array}{l}\text { Clement and Vandenberghe } \\
\text { (2000) }\end{array}$ & Qualitative & Grounded theory & Motivation to collaborate & $\begin{array}{l}\text { Concept of Collegiality according to (Little, } \\
\text { 1990) }\end{array}$ & Yes \\
\hline 9. & Coburn and Russel (2008) & Qualitative & $\begin{array}{l}\text { Social capital theory/social } \\
\text { network analysis }\end{array}$ & No specific motivation concept & Professional (learning) communities & Yes \\
\hline 10. & Collinson and Cook (2004) & Qualitative & No specific theory & Motivation to collaborate & $\begin{array}{l}\text { Focus on sharing of knowledge, skills, } \\
\text { and insights }\end{array}$ & Yes \\
\hline 11. & Conley et al. (2004) & Quantitative & $\begin{array}{l}\text { Hackman and Oldham's (1980) work } \\
\text { group effectiveness model }\end{array}$ & $\begin{array}{l}\text { Motivation to work (operationalized by } \\
\text { e.g., autonomy and interaction with others) }\end{array}$ & $\begin{array}{l}\text { Operationalized as interdisciplinary } \\
\text { teacher teams }\end{array}$ & Yes \\
\hline 12. & De Lima (2001) & Conceptual & Professional learning communities & No specific motivation concept & $\begin{array}{l}\text { Concept of Collegiality according to (Little, } \\
\text { 1990) }\end{array}$ & No \\
\hline \multirow[t]{2}{*}{13.} & Devos et al. (2014) & Quantitative & Distributed leadership approach & Affective organizational commitment & $\begin{array}{l}\text { Cooperation within the leadership team } \\
\text { and participative decision-making } \\
\text { of teachers }\end{array}$ & Yes \\
\hline & $\begin{array}{l}\text { Drach-Zahavy and Somech } \\
(2002 a, b)\end{array}$ & Quantitative & Educational and organizational theory & No specific motivation concept & No specific collaboration concept & No \\
\hline 14. & Drossel et al. (2018) & Quantitative & Expectancy value theory & $\begin{array}{l}\text { Expectancy value model (Eccles and } \\
\text { Wigfield, 2002) to analyze teachers' } \\
\text { motivation to collaborate. }\end{array}$ & $\begin{array}{l}\text { Subdivided into three categories: } \\
\text { exchange, synchronization, and } \\
\text { co-construction (Gräsel et al., 2006) }\end{array}$ & Yes \\
\hline 15. & Durksen et al. (2017) & Mixed Methods & $\begin{array}{l}\text { Social cognitive theory, } \\
\text { demands-resources theory and } \\
\text { self-determination theory }\end{array}$ & $\begin{array}{l}\text { Combination of social cognitive theory, } \\
\text { demands-resources theory and } \\
\text { self-determination theory }\end{array}$ & $\begin{array}{l}\text { Focus on collaborative learning and } \\
\text { relatedness according to } \\
\text { self-determination theory }\end{array}$ & Yes \\
\hline 16. & Egodawatte et al. (2011) & Qualitative & No specific theory & No specific motivation concept & $\begin{array}{l}\text { Collaborative model that values } \\
\text { consensus building with a focus on } \\
\text { relations between universities and schools. }\end{array}$ & Yes \\
\hline
\end{tabular}

All articles found in line with searc 
Method

Theoretical approach

No specific theoretical approach

17. English and Duncan-Howell Qualitative (2008)

18.

Forte and Flores (2014)

Qualitative

No specific theory

19. Geijsel et al. (2009)

20. Goddard et al. (2000)

21. Goodnough et al. (2009)

Quantitative

Social cognitive theory

Quantitative

Social cognitive theory/collective

teacher efficacy

Qualitative $\quad$ Communities of practice

22. Hew and Hara (2007)

Qualitative

23.

Honingh and Hooge (2014)

Quantitative

School leadership approach

24. Horn and Little (2010)

Qualitative

Professional learning approach

25. Hur and Brush (2009)

Qualitative

26. Jao and McDougall (2016)

27. Johnson et al. (2012)

Qualitative

Quantitative

28. Kaldi and Xafakos (2017)

29. Klassen et al. (2010)

30. Kraft and Papay (2014)

31. Little (1990)

33.

36. Reeves et al. (2017)

37. Ross and Gray (2006)

38. Runhaar et al. (2010)

\section{Mixed methods}

Quantitative

Quantitative

Conceptual

Quantitative

Quantitative

Mixed methods

Quantitative

Quantitative

Quantitative

Quantitative
Communities of practice/social learning theory

Communities of practice

Theory of situated learning, self-determination theory

Social cognitive theory/collective

teacher efficacy

Organization theory

different forms and contents of

teacher collaboration

Peer learning network approach

Social cognitive theory/collective teacher efficacy

Social capital theory

characteristics model

No specific theoretical approach
Motivation concept

Collaboration concept

Selected

No specific theoretical concept

First step to theoretically distinguish

Hackman and Oldham's (1980) job

Transformational leadership approach

AMO-theory/social cognitive theory/goal

orientation theory/transformational

leadership theory
Motivation to teach/to handle problems in practicum

Motivation to teach and to develop

professionally

Self-efficacy

Collective teacher efficacy

Effects of teacher collaboration

Motivation to share knowledge

Motivation to collaborate

No specific motivation concept

Online community software (i.e.,

Facebook group)

Professional learning communities No

Collective teacher efficacy

Communities of practice

Communities of practice

Teacher interactions concerning

curriculum and instruction

Professional communities/communities of Yes

practice/teacher work groups

Participation in online communities

Communities of practice

Motivation to collaborate

Focus on job satisfaction and motivation to teach/turnover rates.

Self-determination theory (SDT)

No specific collaboration concept

Relatedness according to SDT

Collective teacher efficacy

Collective motivation

Motivation to collaborate

Peer collaboration and social support

Differentiates different collaboration forms

and contents (e.g., storytelling and

scanning, sharing, aid and assistance and joint work)

No specific motivation concept

Cooperative learning

Teachers' advice networks

Collective teacher efficacy

Social capital approach

No specific motivation concept

Internal work motivation/self-efficacy

Work group enhancement

Job satisfaction and teacher confidence as prerequisites for teacher motivation Teacher efficacy/teacher commitment

Types of teacher collaboration according to TIMSS data

Professional learning communities No

Occupational self-efficacy/learning goal Asking for feedback
Participation in professional development Yes

No specific motivation concept 
TABLE 3B | Continued

\begin{tabular}{|c|c|c|c|c|c|c|}
\hline No. & References & Method & Theoretical approach & Motivation concept & Collaboration concept & Selected \\
\hline 39. & Sato and Kleinsasser (2004) & Qualitative & $\begin{array}{l}\text { A combination of many different } \\
\text { theoretical constructs }\end{array}$ & No specific motivation concept & Different forms of teacher collaboration & No \\
\hline 40. & Scribner et al. (2002) & Qualitative & $\begin{array}{l}\text { Professional communities/micropolitics } \\
\text { of education }\end{array}$ & Need satisfaction/Professional autonomy & Professional learning communities & Yes \\
\hline 41. & Sehgal et al. (2017) & Quantitative & $\begin{array}{l}\text { Teacher effectiveness research/teacher } \\
\text { self-efficacy/transformational } \\
\text { leadership approach }\end{array}$ & Teacher self-efficacy & Teacher collaboration scale & No \\
\hline 42. & Somech (2005) & Quantitative & $\begin{array}{l}\text { 1. Personal and Team empowerment } \\
\text { approach/2. organizational commitment/3. } \\
\text { professional commitment/4. organizational } \\
\text { citizenship behavior (OCB) }\end{array}$ & Need satisfaction/sense of empowerment & Teamwork & Yes \\
\hline 43. & $\begin{array}{l}\text { Somech and Drach-Zahavy } \\
(2000)\end{array}$ & Quantitative & Self-efficacy and collective efficacy & $\begin{array}{l}\text { Job satisfaction, self- and collective } \\
\text { efficacy }\end{array}$ & Collective efficacy & Yes \\
\hline 44. & Staessens (1993) & Qualitative & Socio-cultural approach & Goal consensus/motivation to teach & $\begin{array}{l}\text { Communication and cooperation between } \\
\text { teachers as basic for the school culture }\end{array}$ & No \\
\hline \multirow[t]{2}{*}{45.} & $\begin{array}{l}\text { Szczesiul and Huizenga } \\
\text { (2014) }\end{array}$ & Qualitative & $\begin{array}{l}\text { Principal leadership/socio-cultural } \\
\text { perspective/Social cognitive theory }\end{array}$ & Self-efficacy/motivation to teach & Common planning time/School culture & Yes \\
\hline & $\begin{array}{l}\text { Szczesiul and Huizenga } \\
\text { (2015) }\end{array}$ & Qualitative & Social cognitive theory/teacher leadership & Self-efficacy & Inquiry-based teacher collaboration & No \\
\hline 46. & Thoonen et al. (2011) & Quantitative & $\begin{array}{l}\text { Framework for large-scale reform } \\
\text { (Leithwood et al., 2002), } \\
\text { Expectancy-value-model, } \\
\text { Social-cognitive theory }\end{array}$ & $\begin{array}{l}\text { Expectancy-value-(affect)-model } \\
\text { (operationalized by self-efficacy, } \\
\text { internalization of school goals, tolerance of } \\
\text { uncertainty, well-being) }\end{array}$ & $\begin{array}{l}\text { Organizational conditions of Professional } \\
\text { learning communities }\end{array}$ & Yes \\
\hline 47. & Thornton (2006) & $\begin{array}{l}\text { Qualitative/multiple } \\
\text { case study } \\
\text { approach }\end{array}$ & No specific theoretical approach & No specific motivation concept & No specific collaboration concept & No \\
\hline 48. & Vangrieken et al. (2015) & Review & $\begin{array}{l}\text { Systematic literature search and } \\
\text { narrative analysis }\end{array}$ & No specific motivation concept & No specific collaboration concept & No \\
\hline 49. & Vescio et al. (2008) & Review & Systematic literature review & $\begin{array}{l}\text { Professional learning communities and } \\
\text { communities of practice }\end{array}$ & $\begin{array}{l}\text { Professional learning communities and } \\
\text { communities of practice }\end{array}$ & No \\
\hline 50. & $\begin{array}{l}\text { Voelkel and Chrispeels } \\
\text { (2017) }\end{array}$ & Quantitative & $\begin{array}{l}\text { Professional communities/social cognitive } \\
\text { theory }\end{array}$ & Collective efficacy & Professional learning communities & No \\
\hline 51. & Wolgast and Fischer (2017) & Quantitative & Social interdependency theory & No specific motivation concept & Social interdependency theory & No \\
\hline 52. & Xu (2015) & Qualitative & No specific theoretical approach & No specific motivation concept & $\begin{array}{l}\text { Distinguishes different types } \\
\text { of collaboration }\end{array}$ & No \\
\hline 53. & YIIdırım (2014) & Quantitative & $\begin{array}{l}\text { Theoretically constructed model of } \\
\text { teachers' professional well-being }\end{array}$ & $\begin{array}{l}\text { Professional well-being (operationalized by } \\
\text { e.g., self-efficacy and motivation) }\end{array}$ & No specific collaboration concept & Yes \\
\hline 54. & Zimmerman (2006) & $\begin{array}{l}\text { Conceptual/review } \\
\text { of research }\end{array}$ & $\begin{array}{l}\text { Leadership and Organizational } \\
\text { Change approach }\end{array}$ & Combination of different approaches & Combination of different approaches & No \\
\hline
\end{tabular}


that teachers' organizational commitment and motivation is not only mediated by principals' leadership, but also by assistant principals and individual teachers with a leadership role as well as the involvement of all teachers in participative decisionmaking, i.e., a collegial leadership style focused on empowering the teaching staff.

Based on a longitudinal study, Szczesiul and Huizenga (2014) question these findings by arguing that the effects of principals' leadership on teacher motivation and teacher collaboration are not always positive as they depend on the teaching staff as well as individual teaching teams.

\section{Work Conditions and Supporting Tools}

Leadership practices are closely linked to teachers' work conditions in schools. Whereas transformational leadership practices can strengthen teachers' motivation and professional learning (Thoonen et al., 2011), school leaders should support teacher motivation and school organizational conditions by fostering transformational leadership dimensions and a collaborative school climate (Thoonen et al., 2011).

Teacher collaboration through online tools has also been proven to be a relevant teaching method in teacher education programs. As such, there is empirical evidence that team-based learning for in-service teachers reinforces teachers' motivation to collaborate with other teachers and to offer students more stimulating learning opportunities.

English and Duncan-Howell (2008) argue that social media tools such as Facebook $@$ help to create supportive learning environments for pre-service teachers. Using data produced via a Facebook@ group page in Australia, they analyze preservice teachers' experiences and behaviors during their teaching practicum and suggest that teachers should use such tools more frequently (English and Duncan-Howell, 2008).

Hew and Hara (2007) found four motivators for sharing information in teacher online communities: 1. collectivism (i.e., improving the welfare of community members), 2. reciprocity (i.e., receiving help from others and giving back), 3. personal gain (i.e., sharing to gain new knowledge), and 4. altruism (i.e., empathy for other teachers).

\section{Policies and Development Programs}

Although policymakers and administrators have increasingly used provisions with the aim of fostering teacher collaboration, there is still a lack of studies that systematically analyze the impact of political initiatives and policy frameworks on teachers' motivation to collaborate.

Educational researchers studying collaboration from a network perspective direct their attention to the effects of the patterns of social relations on both the means through which teacher collaboration is realized as well as teachers' individual behavior (Moolenaar, 2012). Against this background, Coburn and Russel (2008) study how district policies influence teachers' social networks in elementary schools. Drawing on quantitative and qualitative network data, they find that policies can have an effect on the structure and depth of teacher collaboration, the access to expertise that they afford, as well as the routines and level of trust in teachers' interactions.
Furthermore, teachers' motivation to collaborate is supported by common planning time and smaller numbers of students to teach. The more often teacher teams meet, the more teachers are motivated and committed to both the team's mission and the success of the team in achieving its goals (Somech and Drach-Zahavy, 2000; Somech, 2005).

Szczesiul and Huizenga (2014) explore the way teachers' social interactions influence their motivation to engage in collaboration. According to teachers' self-expressions, strategic scheduling allowing for common planning time increases their collaboration efforts. Collinson and Cook (2004) confirmed the importance of time for teacher interaction and in-depth discussions for teachers' motivation to collaborate. These findings are also supported by Moolenaar et al. (2012) who suggest that the density of work-related social ties affects teachers' perceptions of policy initiatives. However, those policy initiatives do not seem able to fully ensure the development of trust through frequent meetings. One reason for this lacking capability of policy initiatives is related to the observation that teachers are more likely to be close to or trust other teachers who they have known longer or with whom they have had prior relationships (Coburn and Russel, 2008). It is also observed that teachers fall back on "moment-by-moment exchanges" when they are confronted with external expectations (Little, 1990, p. 514; Collinson and Cook, 2004).

\section{Constraints on Collaboration}

Studies focusing on teachers' motivation to collaborate also refer to different barriers or constraints (Thornton, 2006; Jao and McDougall, 2016). However, most of the studies that also refer to the barriers to teacher collaboration do so in an incidental way. It can be assumed that future research projects will identify even more factors. At the same time, it is also observed that when teachers recognize the benefits of collaboration in terms of student achievement and their own professional growth, they develop strategies to overcome constraining factors (Jao and McDougall, 2016).

\section{Effects of Teacher Collaboration on Teacher Motivation}

Teachers working in teams show a higher internal work motivation (Conley et al., 2004). In this section, the empirical findings concerning the effects of teacher collaboration on teacher motivation will be outlined, discussed and reflected against the second research question in more detail.

\section{Well-Being and Job Satisfaction}

Teacher collaboration and teacher motivation are connected with teacher well-being and job satisfaction in international surveys such as TALIS (OECD Teaching and Learning International Survey). TALIS is the first international survey focused on teachers and school leaders in relation to six areas: learning environment; appraisal and feedback; teaching practices and classroom environment; development and support; school leadership; self-efficacy and job satisfaction. Hierarchic regression analysis drawing on TALIS 2013 dataincluding teachers' individual, professional and organizational 
characteristics - shows that organizational characteristics explain the largest share (two thirds) of total explained variance in teachers' well-being and motivation (Yildırım, 2014). The most influential organizational characteristics are collaboration among staff, classroom climate, feedback and assessment, and the climate of the school (Yildirim, 2014).

A further series of international assessments providing information on teacher collaboration is the international comparative study of student achievement, Trends in International Mathematics and Science Study (TIMSS), which is conducted by the International Association for the Evaluation of Educational Achievement. TIMSS evaluates students' educational achievements in the fourth and eighth grades in mathematics and science. Data provided by this study build a source to analyze the types and frequencies of collaboration and its effects on job satisfaction and teacher confidence. Empirical studies based on TIMSS data gathered in the United States demonstrate that collaboration involving the visiting of other classrooms as well as collaborative planning significantly influence job satisfaction (Reeves et al., 2017).

Role of Cultural Context, Norms, Values, and Meaning Empirical results indicate that the cultural context influences motivation beliefs in different cultural settings. In individualist cultures such as the United States or Germany, people highlight individual objectives, describe the self as autonomous and evaluate the costs and benefits of collaboration (Klassen et al., 2010). In collectivist countries, such as Korea, people emphasize in-group goals, circumscribe the self as interdependent and highlight in-group needs when describing motivation and behavior (Goddard et al., 2000; Klassen et al., 2010). One explanation for the influence of cultural context, norms, values, and meaning can be found in the concept of collective teacher efficacy. In each school, shared beliefs may shape the culture and thus have an influence on teachers motivations as well as their willingness to collaborate. As Goddard et al. (2000) note, it seems that teachers' "shared beliefs shape the normative environment of schools. These shared beliefs are an important aspect of the culture of a school. Collective teacher efficacy is a way of conceptualizing the normative environment of a school and its influence on both personal and organizational behavior. That is, teachers' beliefs about their faculty's capability to educate students constitute a norm that influences the actions and achievements of schools" (Goddard et al., 2000, p. 496). In this quote, the authors particularly emphasize the possible effect of beliefs about the quality of a teacher's school as well as the interdependency between the culture which shapes a school and teacher efficacy. Hence, it is not only individual characteristics that shape an individual teacher's efficacy, but also a collective dimension, i.e., the collective teacher efficacy that shapes motivation and collaboration within schools and vice verca. In other words, because the "tendency to abide by the approval of others will be dependent on the level of relatedness with these others" (De Brabander and Martens, 2014, p. 38), relatedness is shaped not only by culture but also by subjective norms, values, and beliefs. Through collaboration, teachers can internalize norms that positively shape their motivation and beliefs and serve as a foundation for trustful and constructive relationships (Runhaar et al., 2010). In this line of research, Horn and Little (2010) explore how leadership practices and norms are fostered through teacher interaction and structured collaboration. Based on audiotaped and videotaped records of teachers' work group interactions over a period of 2 years, the authors show that the practices and norms of group leadership affect teachers' interactions, conversational routines, and motivation to improve (Horn and Little, 2010).

In defining teacher efficacy as a teacher's belief in being capable of influencing student learning, the role of norms and values is strongly related to teacher efficacy and teacher motivation. Empirical studies on the connection between teacher motivation and collaboration show that teachers, when learning collaboratively, have higher levels of efficacy and learning beliefs (Durksen et al., 2017) as well as increased knowledge of and motivation to achieve goals, teacher change, and professional development (Egodawatte et al., 2011).

\section{Role of Social Support Networks for Pre-service Teachers}

Social networks as a source of support and motivation are especially relevant for pre-service teachers. Apart from personal traits, pre-service teacher motivation is shaped by formal and informal interaction with other teachers (Kaldi and Xafakos, 2017, p. 256). Novice teachers seem to need more support through collaboration with peers and mentors. Experienced peers can offer emotional support and inspiration and help to locate resources. At the same time, they are more motivated and freer to develop and implement new ideas for teaching and to achieve personal goals of professional development (Kaldi and Xafakos, 2017).

\section{DISCUSSION}

In this section, the findings of the inductive analysis are presented, synthesized, and discussed. As part of the withinand between-study analyses conducted for this article, the aim was not only to answer the research questions by deductively analyzing the studies but also to re-analyze the literature inductively in order to remain open to new findings and to move from specific observations to broader generalizations. Results of this synthesis, which proved to be very important for this study, are discussed in this section. They lead to the synthesis of (1) ambiguities, which can be traced back to (2) different definitions, understandings, and operationalizations of the concepts of teacher collaboration and motivation as well as inconsistencies in their use. The elaboration of the constructs of teacher motivation and teacher collaboration reveals (3) inconsistencies with respect to the conception of teacher autonomy.

\section{Ambiguities}

Though most studies show positive effects of teacher collaboration on teacher motivation and many empirical results could be replicated, the analysis also uncovered contradictions and inconsistencies. The effects of collaboration are variable and depend on the operationalization of the construct of 
collaboration or the items used in surveys. Whereas, for example, work shadowing and collaborative planning have significant effects on teacher motivation (Reeves et al., 2017), collaborative teaching in the form of discussions with other teachers on how to teach, sharing teaching experiences, and intending to implement new ideas together with other teachers do not contribute to teacher motivation (Reeves et al., 2017).

It is unclear whether or not teacher collaboration reduces workload. However, some studies indicate that teacher collaboration may contribute to job satisfaction and motivation by reducing stress, workload and burnout (Kyriacou and Sutcliffe, 1977; Vangrieken et al., 2015). Furthermore, pressure exerted by state or non-state actors to strengthen collaboration may produce an avoidance posture. Teachers in Portugal, for instance, noted problems and limitations of teacher collaboration, especially when they are forced into it by governments or other non-school actors (Forte and Flores, 2014).

\section{Collaboration and Motivation as Constructs}

Ambiguities and contradictory findings can also be traced back to different definitions, understandings, and operationalizations of the concepts of teacher collaboration and motivation as well as inconsistencies in their use. Many of the articles reviewed for the current study use neither a specific theoretical approach nor a clear definition when analyzing teacher motivation. One reason for the different constructs and theoretical elaborations of teacher collaboration can be found in the research tradition. Research on teacher collaboration and teacher motivation has developed from different disciplines (e.g., psychology, education, sociology, economics, and political science) and sub-disciplines (e.g., education psychology, social psychology, organization psychology, political psychology) with differing theoretical perspectives. What is more, different operationalizations of the constructs of collaboration and motivation in empirical studies may lead to inconsistent effects (Meirink et al., 2010; Honingh and Hooge, 2014; Reeves et al., 2017). Methodological limitations with respect to varying conceptualizations of the constructs of motivation and collaboration do not only render the comparison of the findings difficult, but also inhibit the implementation of a valid meta-analysis. Against this background, this section discusses the use of the constructs of collaboration and motivation in the literature analyzed for this article.

\section{Collaboration as a Construct}

In the literature, collaboration is often regarded as a problematic construct because of its divergent meanings and operationalizations in theoretical and empirical studies. Moreover, the different purposes of collaboration are a subject of discussion and criticism across the literature (Honingh and Hooge, 2014; Reeves et al., 2017).

According to Sawyer (2005), we can distinguish between collaboration and cooperation by stressing that collaboration includes partners in the process of doing their work together as opposed to cooperation in which partners split the work and combine each of their partial results into the final outcomes (see also Vangrieken et al., 2015, p. 23). Whether researchers prefer to use teacher collaboration or teacher cooperation depends on their home country or the language used. In the American academic literature, the term teacher collaboration is more common. In contrast, scholars from other countries, such as Germany, more frequently use the term teacher cooperation ${ }^{1}$.

Different meanings and understandings of teacher collaboration also find their expression in various terms used to describe the phenomenon. The literature on teacher collaboration draws on many different expressions, such as teacher teams (e.g., Pounder, 1999), professional communities (e.g., Coburn and Russel, 2008; Thoonen et al., 2011), professional learning communities (e.g., Scribner et al., 2002; Vescio et al., 2008), or communities of practice (e.g., Hew and Hara, 2007; Goodnough et al., 2009).

With the aim to develop more empirical clarity, scholars have started to distinguish between different forms of teacher collaboration that arise. The next section will deal with this issue and outline the different distinctions found in the literature analyzed for this article.

\section{Forms, Types, and Qualities of Collaboration}

The literature analyzed for this review is not only inconsistent with respect to the understanding of collaboration, but also in terms of the differentiation of the various types and forms teacher collaboration may take. Little (1990) is probably one of the first authors discerning four forms of teachers' collegial relationships: storytelling and scanning for ideas; aid and assistance; sharing; and joint work. These forms are situated along a continuum from independence to interdependence.

\section{Motivation as a Construct}

Although the motivational aspects of collaboration in education are well-documented, less is known about the diverse use of motivation theories and the implications motivation theories have for study results. The idea of social influences on motivation has a long history within social cognitive theory (Bandura, 1989), postulating vibrant interactions between individual attributes, behavior, and the social context.

Motivation theories used to study social or collaborative aspects of teacher motivation are manifold and include attribution theory, self-determination theory, self-worth theory, flow theory, social-cognitive theory, theory of planned behavior, and person-object theory of interest. Most of the articles however, use a combination of different approaches or do not specify their motivation concept. Seven of the 25 articles analyzed for this review adapted social cognitive theory and two adapted an expectancy-value-model (Thoonen et al., 2011; Drossel et al., 2018). The remaining studies either did not specify their theoretical conceptualizations of motivation (see e.g., Egodawatte et al., 2011) or used socio-culturally oriented theories instead of motivation theories [e.g., work group effectiveness model (Conley et al., 2004; Honingh and Hooge, 2014)].

\footnotetext{
${ }^{1}$ The avoidance of the term 'collaboration' in the German literature may be traced back to Germany's history and the use of the term 'collaboration' during the Second World War.
} 
Scholars studying teacher motivation or motivational aspects of teacher behavior use a diverse range of theories and the concept of motivation differs significantly. This conceptual difference is not only related to the motivation theories applied, but also to the question of whether a global or a task-specific motivation is the focal point of interest. Teacher motivation may refer to the adaptation of team coaching or co-construction (i.e., task-specific motivation) or to a teacher's general intention to collaborate with other colleagues (global motivation concerning collaboration). A task-specific teacher motivation, for instance, may apply to teachers' motivation to collaborate with other colleagues (Szczesiul and Huizenga, 2015, p. 375). A global motivation, in contrast, is associated with teachers' general tendency to collaborate (Han and Yin, 2016).

The conception of autonomy is particularly noticeable in the literature on teacher collaboration. Many scholars stress the notion of independence within the concept of autonomy, which excludes collaboration and impedes the development of a high degree of social embeddedness in the staff (Lortie, 1975).

This is remarkable because self-determination theory (SDT) (e.g., Ryan and Deci, 2000)-one of the most important motivation theories in education research - stresses the fundamental role of autonomy for motivational processes. According to SDT, motivation is based on three psychological needs: competence, autonomy, and relatedness (see Figure 1).

The three psychological needs serve as a basis for motivation, which in turn ranges on a scale from intrinsic to extrinsic motivation (i.e., intrinsic, integrated, identified, introjected, external motivation, and amotivation). Whereas, intrinsic motivation is defined as behavior for its own sake, extrinsic motivation is related to extrinsic goals to be achieved by an individual. Extrinsic motivation may also be internalized by individuals, relating extrinsic motives with personal values and thus transforming extrinsic motivation into a specific degree of intrinsic motivation (Ryan and Deci, 2000). "Accordingly, innate psychological needs for competence, relatedness, and autonomy concern the deep structure of the human psyche, for they refer to innate and life-span tendencies toward achieving effectiveness, connectedness, and coherence" (Deci and Ryan, 2000, p. 229).

The definition of autonomy and relatedness as basic needs for motivation has led us to re-analyze the literature found for this review with regard to its conceptualizations of autonomy. Results of this inductive analysis are discussed in the next section.

\section{Teacher Autonomy}

Limitations of teacher collaboration and motivation are often related to a loss of autonomy. From this perspective, teacher collaboration as shared decision-making is perceived as a limiting factor concerning teacher autonomy. Empirical observations in line with this reasoning point out the negative effects of teacher collaboration on teacher motivation (e.g., Moolenaar, 2012), and thereby contradict the positive effects discovered in longitudinal surveys and many cross-sectional studies.

However, as already indicated above, the literature analyzed for this article is also inconsistent concerning its understanding of teacher autonomy. In analyzing the literature for this article according to its conceptualizations of teacher autonomy, it became evident that two contrasting understandings of teacher autonomy seem to flow through the academic literature on teacher collaboration and teacher motivation.

On the one hand, scholars demonstrate how teacher autonomy as an active and independent study strategy can increase the chances of teacher collaboration outside the own school (Little, 1990). From this perspective, teachers are acting as autonomous isolates, being independent with regard to teaching, curriculum development, school functioning, professional development or teacher change and being immutable to external influences. This negative attitude toward collaboration based on an individualist understanding of autonomy is often adapted and propagated by teachers who regard teacher collaboration as a threat to their freedom at work (Vangrieken et al., 2015, p. 36).

On the other hand, in the 1990s scholars already argued that teacher autonomy as an active and independent study strategy can increase the chance of teacher collaboration outside the own school (Little, 1990). Authors arguing along this line of reasoning emphasize that autonomy and collegiality are closely linked to one another and that interactions between teachers can build a source of autonomous motivation (Clement and Vandenberghe, 2000). Furthermore, it is shown that autonomous motivation often leads to "meaningful collegial contacts" (Clement and Vandenberghe, 2000, p. 91). Scribner et al. (2002) demonstrate that professional autonomy does not imply that teachers define their practice in isolation or that the autonomy that teachers seek to have in their work impedes them from collaborating. They further argue that the "degree of professional autonomy that principals provide teachers can be directly related to the strength of professional community" (Scribner et al., 2002, p. 70).

From the first perspective, autonomy hinders collaboration. From the latter, collaboration is facilitated by autonomy. One explanation for this inconsistent argumentation in the literature analyzed for this review is scholars' heterogeneous use of the concept of autonomy. In the past, autonomy has often been defined as independence, isolation, or alienation. However, as outlined above, other scholars and motivation theorists contrast this argumentation by perceiving autonomy as the main element of successful teacher collaboration (e.g., Scribner et al., 2002). Although some authors regard autonomy as the opposite of interconnectedness, associated with independence and non-reliance, other understandings are more compatible with motivation theories such as SDT. These latter conceptualizations of autonomy include individuals' need for both autonomous action and social embeddedness (e.g., to make their own choices and to be the origin of their own actions in collaborative teams promoting connectedness).

Table 5 summarizes the distinction between these two perspectives on autonomy. The left-hand column outlines the perspective that views teacher autonomy as hindering teacher collaboration and motivation. The right-hand column presents key points of the other perspective, which is labeled here as "collaborative autonomy" (see Figure 2).

Collaborative autonomy is related to an understanding of autonomy that supports teacher collaboration and motivation and may be described as a collaborative culture in contrast to a contrived collegiality (Hargreaves and Dawe, 1990, pp. 228-229). 


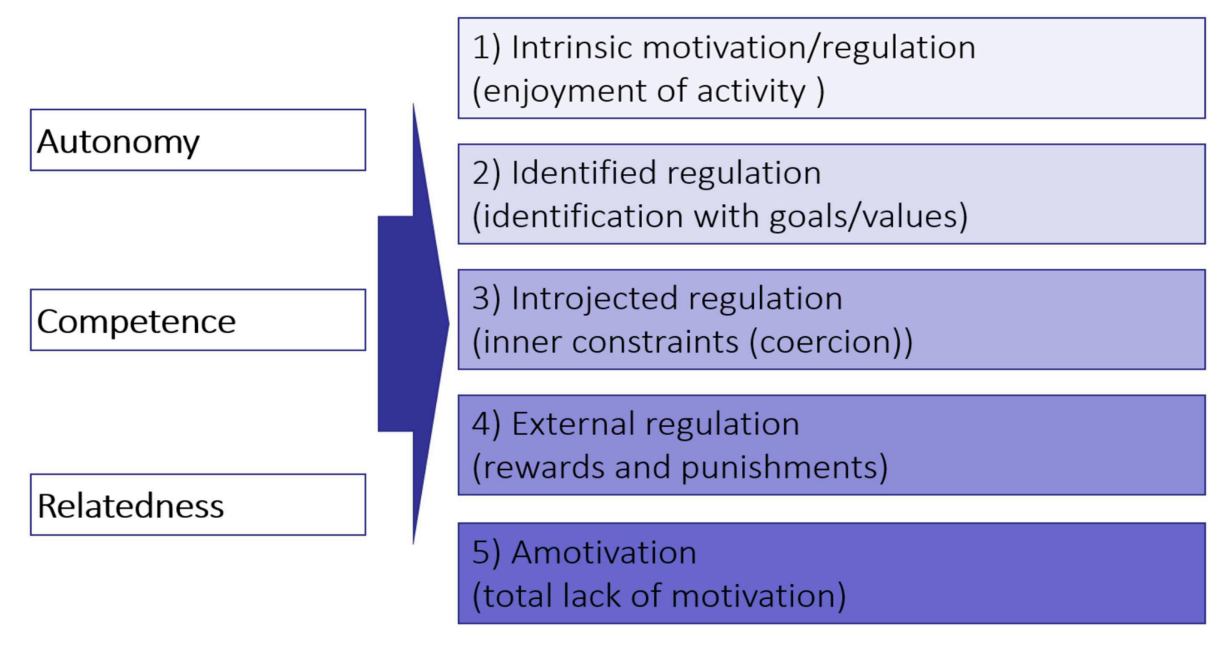

FIGURE 1 | Basic needs according to self-determination theory.

TABLE 4 | Hindering autonomy vs. collaborative autonomy.

\begin{tabular}{ll}
\hline $\begin{array}{l}\text { Autonomy as independence } \\
\text { Individual action determined by } \\
\text { independence of others }\end{array}$ & $\begin{array}{l}\text { Collaborative autonomy } \\
\text { Individual action determined by } \\
\text { reciprocal dependencies }\end{array}$ \\
$\begin{array}{l}\text { Excluding collaboration and } \\
\text { cooperation }\end{array}$ & $\begin{array}{l}\text { Autonomy and social relatedness as basic } \\
\text { psychological needs }\end{array}$ \\
Teachers as individualists, & achieve individual and collective goals \\
mavericks and lone fighters & Teacher motivation is strengthened \\
& through collegial interaction
\end{tabular}

Collaborative autonomy is also supported by empirical findings outlined above, which highlight that teacher collaboration strengthens autonomous motivation (Conley et al., 2004), fosters individual and collective goals through self-determined participation in teacher teams, enhances job satisfaction, and results in a reduction of burnout. In different field studies, scholars could confirm assumptions of SDT by demonstrating that supporting autonomy as compared to control is associated with "more positive outcomes, including greater intrinsic motivation, increased satisfaction, and enhanced well-being" (Deci and Ryan, 2000, p. 234). Even studies based on an expectancy-value model emphasize the fundamental role that a pro-collaborative attitude plays in teachers' motivation to collaborate, implying that "there will be no change in cooperative behavior without a change in attitude" (Drossel et al., 2018, p. 17).

Following this line of reasoning, teacher motivation is based on both autonomy and social relatedness. Social relatedness and teacher collaboration are mutually conditioned, but whereas social relatedness requires trustful relations based on closeness (Coburn and Russel, 2008; Runhaar et al., 2010), autonomy may foster innovation, educational change and school improvement (Egodawatte et al., 2011).

\section{SUMMARY}

This review set out to systematically analyze the interconnection between teacher collaboration and teacher motivation in the academic literature. The aim was to find answers to the questions of what studies can tell us about the motivations of teachers to collaborate with other teachers, and what effects of teacher collaboration on teacher motivation are discussed in the academic literature. Hence, both directions, i.e., the drivers or motivations of teachers to collaborate and the effects of teacher collaboration on teacher motivation, are the focus of the analysis. The general aims of the review were 2 fold. First, its goal was to map and synthesize findings on the relationship between teacher motivation and collaboration. Second, it aimed to find new aspects by qualitatively reconstructing the studies and to interpret the conceptualizations and operationalizations of teacher motivation and collaboration. It was shown that the different drivers for teachers to collaborate have been related by scholars to policies and development programs, time for collaboration, leadership practices, work conditions and supporting tools, individual attributes, and group behavior. Furthermore, constraints on collaboration were discussed as impeding factors for teacher collaboration. The effects of teacher collaboration on teacher motivation were mainly related to wellbeing and job satisfaction, the role of the cultural context, norms, values and meaning, as well as social support networks for teacher development.

Subsequent to the synthesis and discussion of the literature analyzed, the literature was re-analyzed inductively. This final analysis proved to be the most important aspect of this study because it resulted in the identification of inconsistencies and ambiguities. Inconsistencies and ambiguities were traced back to the use of the concepts of teacher motivation and collaboration. It was shown how both the definition and operationalization of these constructs have consequences for the identification of empirical needs and study outcomes. Furthermore, it was 


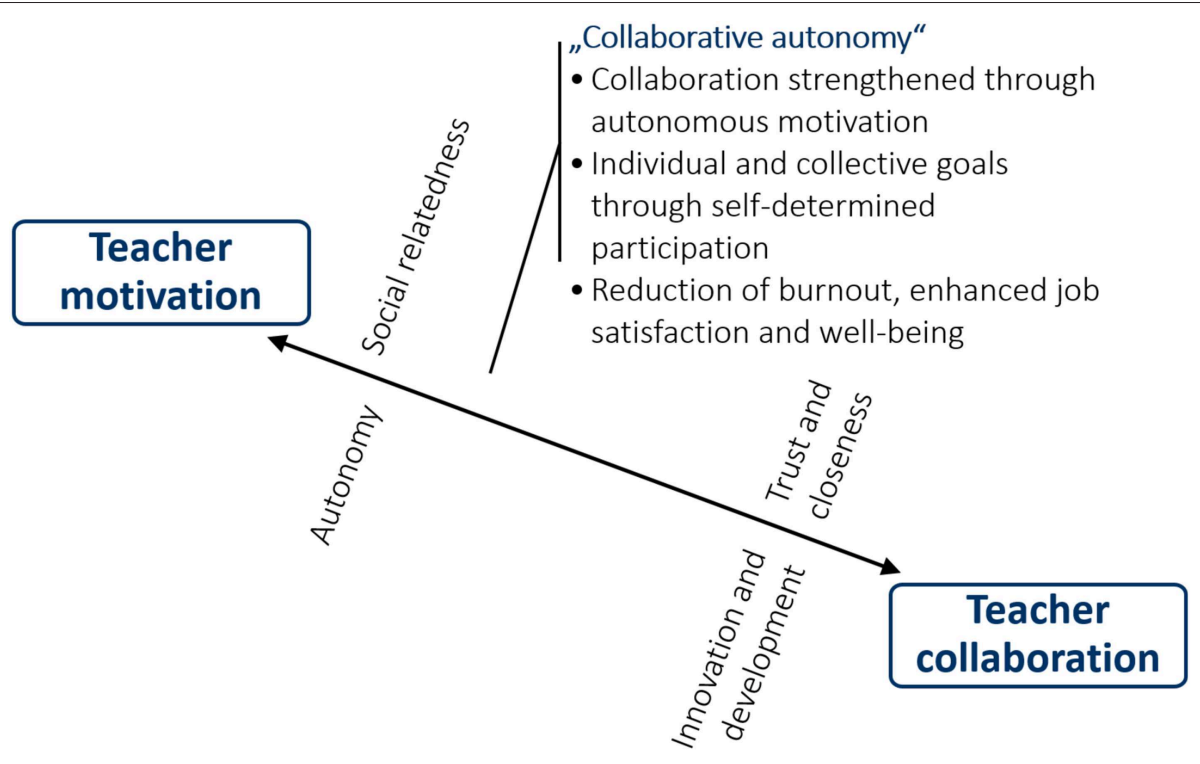

FIGURE 2 | Collaborative autonomy and teacher motivation.

revealed that most of the studies analyzed do not use specific theories to study teacher motivation and teacher collaboration. This is surprising given the manifold theories and validated scales that have been developed to study teacher motivation and teacher collaboration in the past. Hence, inconsistencies in the academic literature are also the result of a lack of theories and methodological rigor in many studies on teacher motivation and teacher collaboration. Even the forms, types, and qualities of both teacher collaboration and teacher motivation are often not specified or distinguished in the academic literature in spite of the fact that the type of motivation or collaboration studied has an impact on study results.

By analyzing the literature according to the studies' use of the constructs of motivation and collaboration, it became evident that limitations of teacher collaboration and motivation are often related to a loss of autonomy. From this perspective, teacher collaboration as shared decision-making is perceived as a limiting factor with regard to teacher autonomy. This finding was surprising given that relatedness is among the key basic needs of motivation according to SDT. According to SDT, it should be assumed that relatedness and collaboration mutually reinforce one another and that collaboration positively affects teacher motivation. This theoretical assumption is also confirmed by most of the empirical studies, although these studies often do not specify the concepts of motivation and collaboration used. These considerations have led to the conclusion that we need to apply an understanding of autonomy that is compatible with collaboration and relatedness. According to this understanding, teachers have a need for both autonomous action and social embeddedness. This understanding of teacher autonomy highlights individuals' autonomy to govern interaction, but also supports the notion of autonomously promoting connectedness or taking part in teacher collaboration.

\section{LIMITATIONS}

Although this review has presented results for scholars setting out to perform empirical research on teacher motivation and teacher collaboration, its limitations need to be considered.

First, results of this review are restricted to the literature analyzed. This literature was detected by systematically applying specific keywords in the most relevant databases (e.g., ERIC). However, the search terms were reduced to "teacher AND motivation," "teacher AND collaboration," "teacher AND cooperation," "collective AND teacher AND efficacy," "cooperative AND learning AND teacher AND education," and "school AND team AND work AND motivation." Other keywords, such as those related to "teacher networks" or "communities" were not applied in this study because preliminary searches with these terms conducted for this review resulted more in literature focused on collaboration between school and out-of-school organizations and third sector participation in schools, which was not the main interest of the current study.

In addition, this review was restricted to peer-reviewed articles and did not include books, articles published in handbooks or edited volumes, dissertations, or gray literature. While many important findings were excluded from this article, this restriction was important in light of the high number of studies found and based on the assumption that the chances of identifying high-quality studies are greater when only peerreviewed articles are included.

A further restriction may be seen in the focus on teachers and corresponding exclusion of other educational actors such as parents, students, individuals working in higher education, further education actors, or out-of-school organizations. Indeed, motivational aspects of collaboration have been increasingly 
stressed in (review) studies in these fields in recent years (e.g., O'Leary and Wood, 2019).

\section{CONCLUSION}

In light of the findings of this study, different conclusions can be drawn. In the following, this final section suggests prospects for further research and implications for research and practice.

\section{Implications for Research}

The current study has reviewed the scientific literature on different facets of the relationship between teacher motivation and teacher collaboration. It has included peer-reviewed articles applying diverse theoretical perspectives and different methodological approaches and has contributed to the current knowledge of the relationship between teacher motivation and teacher collaboration by identifying main related research areas. By including quantitative as well as qualitative studies, this review has moved away from simply studying the effectiveness of complex phenomena in a research field where evidence is heterogeneous (Petticrew, 2015).

The limitations and critiques of the existing literature indicate possible directions for future research. More general research desiderata concern answers to the questions of what motivates teachers to collaborate and what effects collaboration has on teacher motivation. To identify how teacher collaboration affects their motivation and how teachers translate the benefits of collaboration into practice needs further empirical work. Here, more systematic studies with clear concepts of teacher motivation and collaboration-drawing on specific theoretical approaches, applying validated scales, and distinguishing the different forms, types, and qualities of collaboration-could provide more clarity. Not least, this review has shown that studies related to teacher motivation and collaboration have not always been transparent in delineating the theoretical concepts of motivation and collaboration used.

More specifically, the qualities of teacher collaboration and their effects on teacher motivation may be elaborated in future research, including the patterns of social relationships between teachers (e.g., by applying Social Network Analysis), team entitativity and the elaboration of the different understandings of education underlying teacher collaboration, as well as the question of under what circumstances autonomy and collaboration are best combined.

From a motivation theoretical perspective, more research on the effects of social embeddedness on teachers' readiness for action are needed. For instance, we currently still do not know whether the "willingness to abide by the norms of other people that are important in the context of an intended course of action" has a mediated effect (De Brabander and Martens, 2014, p. 40).

Prospects for further research also relate to trust. While studies on teacher collaboration frequently highlight the importance of trust (Scribner et al., 2002) and the positive effect of frequent meetings on trust relationships (Coburn and Russel, 2008), there is still a lack of studies in this area. Do social relations based on trust automatically have a positive effect on teacher motivation? Not least, the results of studies conducted by other scientists point to obstructive effects of high levels of trust in teaching staff. Trusting relationships can even inhibit independent thinking and innovation (e.g., Staessens, 1993; De Lima, 2001). Trust may, for instance, prevent teachers from building new collaborations or from trying out new teaching practices (Staessens, 1993; De Lima, 2001). Hence, future studies may elaborate whether trust might also be a hindering factor and, if so, under what conditions it has positive effects and when it is obstructive. In addition, the different types of trust are generally not differentiated in the literature analyzed for this article (e.g., relational trust needs to be distinguished from the general tendency to trust others) (e.g., Kolleck and Bormann, 2014; Kappauf and Kolleck, 2018).

Finally, future research could focus on the interrelation between teacher motivation, teacher autonomy, and teacher collaboration by further unraveling the circumstances under which autonomy, motivation, and collaboration best support instructional practices. How can autonomy and collaboration best be combined and realized to improve instructional quality? Systematic empirical studies that provide answers to this question could contribute to a better understanding of when autonomy does not exclude collaboration. More systematic studies could result in an overview, providing information on when teacher collaboration and motivation are related to either a gain or a loss of autonomy.

\section{Implications for Practice}

Practical implications of this review include the enhancement of teacher motivation. It is particularly helpful for educational administrators and policymakers to formulate practical strategies to stimulate teachers to cooperate and to increase motivation to determine how to attract potential teachers and how to retain them in teaching.

An emerging number of political programs, school initiatives, media reports, and scholars engaged in school development programs urge the fostering of teacher collaboration and motivation in schools. This review provides practitioners with the most recent findings on the motivators or drivers of teacher collaboration. Different studies have already shown that teacher collaboration directly effects teacher motivation, which in turn is a key determinant of student motivation (Vangrieken et al., 2015). Practitioners could learn from these findings and implement new ways to support teacher collaboration and motivation while at the same time strengthening teacher autonomy. Research results show different paths through which schools make sure that teachers actually want to collaborate; however, there is still a need for more research on the question of what types of collaboration have a positive effect on teacher motivation.

School principals and teachers' working conditions have very important functions. Teacher collaboration can be supported by providing teachers with extra time for collaboration as well as group tasks which, in contrast to individual tasks, foster interdependence, shared goals (Kolleck et al., 2019), and responsibility. Principals and administrators should implement structures and a culture that support teachers' social interactions in school and foster social patterns of support for teacher development. Furthermore, faith in the competencies of team 
members could be reinforced by principals through constructive discussion and a body of shared knowledge.

Another aspect important for educational practice applies to teachers' conception of autonomy. Previous research has demonstrated the fundamental effect that teachers' subjective perception of the relevance of collaboration has on their engagement in collaboration (e.g., Drossel et al., 2018). This implies the need to increase the relevance of cooperative aspects in teacher education and training with the aim of supporting the individual internalization of the importance of collaboration and a collaborative understanding of teacher autonomy.

Results of this review further stress the importance of creating a collaborative school climate, which includes supporting autonomy by giving teachers the chance to take part in decisions concerning collaborative school structures as well as collaborative initiatives implemented from the bottom up. This implies acknowledging that teachers are flexible to make data-based changes in classroom instruction and management, encouraging teacher feedback and learning, as well as continually evaluating "collaborative efforts lest they move to the dark side of contrived collegiality" (Datnow, 2011, p. 158). It further implies creating an awareness among (novice) teachers that autonomy does not exclude collaboration. This can be achieved by involving

\section{REFERENCES}

Al-Natour, M., Amr, M., Al-Zboon, E., and Alkhamra, H. (2015). Examining collaboration and constrains on collaboration between special and general education teachers in mainstream schools in Jordan. Int. J. Spec. Educ. 30, 64-77. Available online at: https://eric.ed.gov/?id=EJ1094801

Ammentorp, L., and Madden, L. (2018). Learning from others: developing preservice teachers' workplace skills. Educ. Forum 85-96. doi: 10.1080/00131725.2018.1385274

Baleghizadeh, S., and Gordani, Y. (2012). Motivation and quality of work life among secondary school EFL teachers. Aust. J. Teacher Educ. 37, 30-42. doi: 10.14221/ajte.2012v37n7.8

Bandura, A. (1989). Perceived self-efficacy in the exercise of personal agency. J. Appl. Sport Psychol. 2, 411-424. doi: 10.1080/10413209008406426

Bandura, A. (2005). "The evolution of social cognitive theory," in Great Minds in Management, eds K. G. Smith and M. A. Hitt (Oxford: Oxford University Press), 9-35.

Baumeister, R. F. (2013). "Writing a literature review," in The Portable Mentor. Expert Guide to a Successful Career in Psychology, ed M. J. Prinstein (New York, NY: Springer), 119-132. doi: 10.1007/978-1-4614-3994-3_8

Bearman, M., Dawson, P., and Dawson, P. (2013). Qualitative synthesis and systematic review in health professions education. Med. Educ. 47, 252-260. doi: $10.1111 /$ medu. 12092

Benoliel, P., and Schechter, C. (2017). Is it personal? Teacher's personality and the principal's role in professional learning communities. Improv. Schools 20, 222-235. doi: 10.1177/1365480217703725

Bigsby, J. B., and Firestone, W. A. (2017). Why teachers participate in professional development: lessons from a schoolwide teacher study group. N. Educ. 13, 72-93. doi: 10.1080/1547688X.2015.1063743

Chapman, C., and Hadfield, M. (2010). Realising the potential of schoolbased networks. Educ. Res. 52, 309-323. doi: 10.1080/00131881.2010. 504066

Ciampa, K., and Gallagher, T. L. (2016). Teacher collaborative inquiry in the context of literacy education: examining the effects on teacher selfefficacy, instructional and assessment practices. Teach. Teach. 22, 51-67. doi: 10.1080/13540602.2016.1185821 teachers in decision-making, initiating their own collaborations, and through collaborative structures in schools (Clement and Vandenberghe, 2000).

\section{AUTHOR CONTRIBUTIONS}

The author confirms being the sole contributor of this work and has approved it for publication.

\section{FUNDING}

This work was supported by the German Research Foundation (Deutsche Forschungsgemeinschaft) under Grant [number KO 4997/1-1; FOR 1745] and the Mercator Foundation (Mercator Stiftung) under Grant [A16015].

\section{ACKNOWLEDGMENTS}

I would like to thank Judith Warren Little, Rick Mintrop, Bruce Fuller (UC Berkeley), and my colleagues at the Department of Education and Psychology at Freie Universität Berlin for comments and suggestions on a previous version of this manuscript.

Clement, M., and Vandenberghe, R. (2000). Teachers' professional development: a solitary or collegial (ad)venture? Teach. Teach. Educ. 16, 81-101. doi: 10.1016/S0742-051X(99)00051-7

Coburn, C. E., and Russel, J. L. (2008). District policy and teachers' social networks. Educ. Eval. Policy Anal. 30, 203-235. doi: 10.3102/0162373708321829

Collinson, V., and Cook, T. F. (2004). Learning to share, sharing to learn: fostering organizational learning through teachers' dissemination of knowledge. J. Educ. Administr. 42, 312-332. doi: 10.1108/09578230410534658

Conley, S., Fauske, J., and Pounder, D. G. (2004). Teacher work group effectiveness. Educ. Administr. Q. 40, 663-703. doi: 10.1177/0013161X04268841

Datnow, A. (2011). Collaboration and contrived collegiality: revisiting Hargreaves in the age of accountability. J. Educ. Change. 12, 147-158. doi: 10.1007/s10833-011-9154-1

De Brabander, C. J., and Martens, R. L. (2014). Towards a unified theory of task-specific motivation. Educ. Res. Rev. 11, 27-44. doi: 10.1016/j.edurev.2013.11.001

De Lima, J. Á. (2001). Forgetting about friendship: using conflict in teacher communities as a catalyst for school change. J. Educ. Change 2, 97-122. doi: 10.1023/A:1017509325276

Deci, E. L., and Ryan, R. M. (2000). The "what" and "why" of goal pursuits: human needs and the self-determination of behavior and the self-determination of behavior. Psychol. Inq. 11, 227-268. doi: 10.1207/S15327965PLI1104_01

Devos, G., Tuytens, M., and Hulpia, H. (2014). Teachers' organizational commitment: examining the mediating effects of distributed leadership. Am. J. Educ. 120, 205-231. doi: 10.1086/674370

Donnellon, A. (1996). Team Talk: The Power of Language in Team Dynamics. Boston, MA: Harvard Business School Press.

Drach-Zahavy, A., and Somech, A. (2002a). Team heterogeneity and its relationship with team support and team effectiveness. J. Educ. Admin. 40, 44-66. doi: 10.1108/09578230210415643

Drach-Zahavy, A., and Somech, A. (2002b). "Building innovative teams: the role of team heterogeneity and interaction processes in teams," in Advances in Psychology Research, ed S. P. Shohov (Nova Science Publishers), 17-131.

Drossel, K., Eickelmann, B., van Ophuysen, S., and Bos, W. (2018). Why teachers cooperate: an expectancy-value model of teacher cooperation. Eur. J. Psychol. Educ. 50, 1-22. doi: 10.1007/s10212-018-0368-y 
Durksen, T., Klassen, R., and Daniels, L. M. (2017). Motivation and collaboration: the keys to a developmental framework for teachers' professional learning. Teach. Teach. Educ. 67, 53-66. doi: 10.1016/j.tate.2017.05.011

Eccles, J. S., and Wigfield, A. (2002). Motivational beliefs, values, and goals. Annu. Rev. Psychol. 53, 109-132. doi: 10.1146/annurev.psych.53.100901.135153

Egodawatte, G., McDougall, D., and Stoilescu, D. (2011). The effects of teacher collaboration in Grade 9 Applied Mathematics. Educ. Res. Policy Pract. 10, 189-209. doi: 10.1007/s10671-011-9104-y

English, R. M., and Duncan-Howell, J. A. (2008). Facebook@ goes to college: using social networking tools to support students undertaking teaching practicum. J. Online Learn. Teach. 4, 596-601. doi: 10.5897/ERR2015.2446

Fink, A. (2014). Conducting Research Literature Reviews: From the Internet to Paper. Los Angeles, CA: Sage Publications.

Forte, A. M., and Flores, M. A. (2014). Teacher collaboration and professional development in the workplace: a study of Portuguese teachers. Eur. J. Teach. Educ. 37, 91-105. doi: 10.1080/02619768.2013.763791

Geijsel, F. P., Sleegers, P. J. C., Stoel, R. D., and Krüger, M. L. (2009). The effect of teacher psychological and school organizational and leadership factors on teachers' professional learning in Dutch schools. Elem. Sch. J. 109, 406-427. doi: 10.1086/593940

Goddard, R. D., Hoy, A., and Hoy, W. (2000). Collective teacher efficacy: its meaning, measure, and impact on student achievement. Am. Educ. Res. J. 37, 479-507. doi: 10.3102/00028312037002479

Goodnough, K., Osmond, P., Dibbon, D., Glassman, M., and Stevens, K. (2009). Exploring a triad model of student teaching: pre-service teacher and cooperating teacher perceptions. Teach. Teach. Educ. 25, 285-296. doi: $10.1016 /$ j.tate.2008.10.003

Gräsel, C., Fussangel, K., and Pröbstel, C. (2006). Lehrkräfte zur Kooperation anregen - eine Aufgabe für Sisyphos? [Encouraging teachers to cooperate - a task for Sisyphus?]. Zeitschrift für Pädagogik. 42, 205-219. doi: 10.1007/978-3-531-94284-1_2

Hackman, J. R., and Oldham, G. R. (1980). Work Redesign. Reading: AddisonWesley.

Han, J., and Yin, H. (2016). Teacher motivation: Definition, research development and implications for teachers. Cogent Educ. 3, 1-18. doi: 10.1080/2331186X.2016.1217819

Hargreaves, A., and Dawe, R. (1990). Paths of professional development: contrived collegiality, collaborative culture, and the case of peer coaching. Teach. Teach. Educ. 6, 227-241. doi: 10.1016/0742-051X(90)90015-W

Hew, K. F., and Hara, N. (2007). Empirical study of motivators and barriers of teacher online knowledge sharing. Educ. Technol. Res. Dev. 55, 573-595. doi: 10.1007/s11423-007-9049-2

Honingh, M., and Hooge, E. (2014). The effect of school-leader support and participation in decision making on teacher collaboration in Dutch primary and secondary schools. Educ. Manag. Administr. Leaders. 42, 75-98. doi: $10.1177 / 1741143213499256$

Horn, I. S., and Little, J. W. (2010). Attending to problems of practice: routines and resources for professional learning in teachers' workplace interactions. Am. Educ. Res. J. 47, 181-217. doi: 10.3102/0002831209345158

Hur, J. W., and Brush, T. A. (2009). Teacher participation in online communities: why do teachers want to participate in self-generated online communities of K-12 teachers? J. Res. Technol. Educ. 41, 279-303. doi: 10.1080/15391523.2009.10782532

Jahan, N., Naveed, S., Zeshan, M., and A Tahir, M. (2016). How to conduct a systematic review: a narrative literature review. Cureus 8:e864. doi: $10.7759 /$ cureus.864

Jao, L., and McDougall, D. (2016). Moving beyond the barriers: supporting meaningful teacher collaboration to improve secondary school mathematics. Teach. Dev. 20, 557-573. doi: 10.1080/13664530.2016.1164747

Johnson, S. M., Kraft, M. A., and Papay, J. P. (2012). How context matters in high- need schools: The effects of teachers' working conditions on their professional satisfaction and their students' achievement. Teach. Coll. Rec. 114, 1-39. Available online at: http://citeseerx.ist.psu.edu/viewdoc/summary? doi $=10.1 .1 .394 .4333$

Kaldi, S., and Xafakos, E. (2017). Student teachers' school teaching practice: the relation amongst perceived self-competence, motivation and sources of support. Teach. Teach. Educ. 67, 246-258. doi: 10.1016/j.tate.2017.05.019
Kappauf, Z., and Kolleck, N. (2018). Vertrauen im Bildungsverbund: skizze einer Theorie zu Dimensionen interpersonalen Vertrauens. Zeitschrift für Erziehungswissenschaft 21, 1045-1062. doi: 10.1007/s11618-018-0812-4

Klassen, R. M., Usher, E. L., and Bong, M. (2010). Teachers' collective efficacy, job satisfaction, and job stress in cross-cultural Context. J. Exp. Educ. 78, 464-486. doi: $10.1080 / 00220970903292975$

Kolleck, N., and Bormann, I. (2014). Analyzing trust in innovation networks: combining quantitative and qualitative techniques of Social Network Analysis. Zeitschrift für Erziehungswissenschaft 17, 9-27. doi: 10.1007/s11618-0140551-0

Kolleck, N., Rieck, A., and Yemini, M. (2019). Goals aligned: predictors of common goal identification in educational cross-sectoral collaboration initiatives. Educ. Manag. Administr. Leaders. doi: 10.1177/1741143219846906

Kraft, M. A., and Papay, J. P. (2014). Can professional environments in schools promote teacher development? Explaining heterogeneity in returns to teaching experience. Educ. Effect. Policy Anal. 36, 476-500. doi: 10.3102/0162373713519496

Kyriacou, C., and Sutcliffe, J. (1977). Teacher stress: a review. Educ. Rev. 29, 299-306. doi: 10.1080/0013191770290407

Leithwood, K., and Jantzi, D., and Mascall, B. (2002). A framework for research on large-scale reform. J. Educ. Change. 3, 7-33. doi: 10.1023/A:1016527421742

Little, J. W. (1990). The persistence of privacy: autonomy and initiative in teachers? Professional relations. Teach. Coll. Rec. 91, 509-536.

Lortie, D. C. (1975). Schoolteacher: A Sociological Study. Chicago, IL: The University of Chicago Press.

Meirink, J. A., Imants, J., and Verloop, N. (2010). Teacher learning and collaboration in innovative teams. Cambridge J. Educ. 40, 161-181. doi: 10.1080/0305764X.2010.481256

Mintrop, R., and Ordenes, M. (2017). Teacher work motivation in the era of extrinsic incentives: performance goals and pro-social commitments in the service of equity. Educ. Policy Anal. Arch. 25, 1-43. doi: 10.14507/epaa.25.2482

Miquel, E., and Duran, D. (2017). Peer learning network: implementing and sustaining cooperative learning by teacher collaboration. J. Educ. Teach. 43, 1-12. doi: 10.1080/02607476.2017.1319509

Moolenaar, N. M. (2012). A social network perspective on teacher collaboration in schools: theory, methodology, and applications. Am. J. Educ. 119, 7-39. doi: $10.1086 / 667715$

Moolenaar, N. M., Sleegers, P. J. C., and Daly, A. J. (2012). Teaming up: linking collaboration networks, collective efficacy, and student achievement. Teach. Teach. Educ. 28, 251-262. doi: 10.1016/j.tate.2011.10.001

Mora-Ruano, J.G., Gebhardt, M., and Wittmann, E. (2018). Teacher collaboration in german schools: do gender and school type influence the frequency of collaboration among teachers? Front. Educ. 3:55. doi: 10.3389/feduc.2018.00055

National Staff Development Council (2001). Standards for Staff Development (Revised). Oxford, OH: Author

Noe, R. A., Noe, A. W., and Bachhuber, J.A. (1990). An investigation of the correlates of career motivation. J. Vocat. Behav. 37, 340-356. doi: 10.1016/0001-8791(90)90049-8

O'Leary, M., and Wood, P. (2019). Reimagining teaching excellence: why collaboration, rather than competition, holds the key to improving teaching and learning in higher education. Educ. Rev. 71, 122-139. doi: 10.1080/00131911.2019.1524203

Onwuegbuzie, A. J., Leech, N. L., and Collins, K. M. T. (2012). Qualitative analysis techniques for the review of the literature. Qual. Rep. 17, 1-28. Retrieved from: https://nsuworks.nova.edu/tqr/vol17/iss $28 / 2$

Penuel, W., Riel, M., Krause, A., and Frank, K. (2009). Analyzing teachers' professional interactions in a school as social capital: a social network approach. Teach. Coll. Rec. 111, 124-163. Available online at: https://eric.ed.gov/?id= EJ826000

Petticrew, M. (2015). Time to rethink the systematic review catechism? Moving from 'what works' to 'what happens'. Syst. Rev. 4:36. doi: 10.1186/s13643-015-0027-1

Petticrew, M., and Roberts, H. (2006). Systematic Reviews in the Social Sciences: A Practical Guide. Oxford: Blackwell. doi: 10.1002/9780470754887

Pounder, D. G. (1999). Teacher teams: exploring job characteristics and workrelated outcomes of work group enhancement. Educ. Administr. Q. 35, 317-348. doi: 10.1177/0013161X99353002 
Reeves, P. M., Pun, W. H., and Chung, K. S. (2017). Influence of teacher collaboration on job satisfaction and student achievement. Teach. Teach. Educ. 67, 227-236. doi: 10.1016/j.tate.2017.06.016

Ross, J. A., and Gray, P. (2006). Transformational leadership and teacher commitment to organizational values: the mediating effects of collective teacher efficacy. School Effect. School Improv. 17, 179-199. doi: 10.1080/09243450600565795

Runhaar, P., Sanders, K., and Yang, H. (2010). Stimulating teachers' reflection and feedback asking: an interplay of self-efficacy, learning goal orientation, and transformational leadership. Teach. Teach. Educ. 26, 1154-1161. doi: 10.1016/j.tate.2010.02.011

Ryan, R. M., and Deci, E. L. (2000). Self-determination theory and the facilitation of intrinsic motivation, social development, and well-being. Am. Psychol. 55, 68-78. doi: 10.1037/0003-066X.55.1.68

Sato, K., and Kleinsasser, R. C. (2004). Beliefs, practices, and interactions of teachers in a Japanese high school English department. Teach. Teach. Educ. 20, 797-816. doi: 10.1016/j.tate.2004. 09.004

Sawyer, R. K. (2005). The Cambridge Handbook of the Learning Sciences. Cambridge: Cambridge University Press. doi: 10.1017/CBO97805118 16833

Scribner, J. P., Hager, D. R., and Warne, T. R. (2002). The paradox of professional community: tales from two high schools. Educ. Administr. Q. 38, 45-76. doi: 10.1177/0013161X02381003

Sehgal, P., Nambudiri, R., and Mishra, S. K. (2017). Teacher effectiveness through self-efficacy, collaboration and principal leadership. Int. J. Educ. Manag. 31, 505-517. doi: 10.1108/IJEM-05-2016-0090

Somech, A. (2005). Teachers' personal and team empowerment and their relations to organizational outcomes: contradictory or compatible constructs? Educ. Administr. Q. 41, 237-266. doi: 10.1177/0013161X04269592

Somech, A., and Drach-Zahavy, A. (2000). Understanding extra-role behavior in schools: the relationships between job satisfaction, sense of efficacy, and teachers' extra-role behavior. Teach. Teach. Educ. 16, 649-659. doi: 10.1016/S0742-051X(00)00012-3

Staessens, K. (1993). Identification and description of professional culture in innovating schools. Int. J. Qual. Stud. Educ. 6, 111-128. doi: $10.1080 / 0951839930060202$

Szczesiul, S., and Huizenga, J. L. (2014). The burden of leadership: exploring the principal's role in teacher collaboration. Improv. Schools 17, 176-191. doi: $10.1177 / 1365480214534545$
Szczesiul, S., and Huizenga, J. L. (2015). Bridging structure and agency: exploring the role of teacher leadership in teacher collaboration. J. Sch. Leadership. 25, 368-411. doi: 10.1177/105268461502500207

Thoonen, E. E. J., Sleegers, P. J. C., Oort, F. J., Peetsma, T. T. D., and Geijsel, F. P. (2011). How to improve teaching practices: the role of teacher motivation, organizational factors, and leadership practices. Educ. Administr. Q. 47, 496-536. doi: 10.1177/0013161X11400185

Thornton, H. (2006). Teachers talking: the role of collaboration in secondary schools in Bangladesh. Compare 36, 181-196. doi: 10.1080/03057920600741180

Vangrieken, K., Dochy, F., Raes, E., and Kyndt, E. (2015). Teacher collaboration: a systematic review. Educ. Res. Rev. 15, 17-40. doi: 10.1016/j.edurev.2015.04.002

Vescio, V., Ross, D., and Adams, A. (2008). A review of research on the impact of professional learning communities on teaching practice and student learning. Teach. Teach. Educ. 24, 80-91. doi: 10.1016/j.tate.2007.01.004

Voelkel, R. H., and Chrispeels, J. H. (2017). Understanding the link between professional learning communities and teacher collective efficacy. School Effect. School Improv. 28, 505-526. doi: 10.1080/09243453.2017.1299015

Walton, R. E. (1973). Quality of work life: what is it? Sloan Manage. Rev. 15, 11-21.

Wolgast, A., and Fischer, N. (2017). You are not alone: colleague support and goaloriented cooperation as resources to reduce teachers' stress. Soc. Psychol. Educ. 20, 836-854. doi: 10.1007/s11218-017-9366-1

$\mathrm{Xu}, \mathrm{H}$. (2015). The development of teacher autonomy in collaborative lesson preparation: a multiple-case study of EFL teachers in China. System 52, 139-148. doi: 10.1016/j.system.2015.05.007

Yildırım, K. (2014). Main factors of teachers professional well-being. Educ. Res. Rev. 9, 153-163. doi: 10.5897/ERR2013.1691

Zimmerman, J. (2006). Why some teachers resist change and what principals can do about it. Natl Assoc. Second. School Princ. Bull. 90, 238-249. doi: $10.1177 / 0192636506291521$

Conflict of Interest: The author declares that the research was conducted in the absence of any commercial or financial relationships that could be construed as a potential conflict of interest.

Copyright (c) 2019 Kolleck. This is an open-access article distributed under the terms of the Creative Commons Attribution License (CC BY). The use, distribution or reproduction in other forums is permitted, provided the original author $(s)$ and the copyright owner(s) are credited and that the original publication in this journal is cited, in accordance with accepted academic practice. No use, distribution or reproduction is permitted which does not comply with these terms. 